
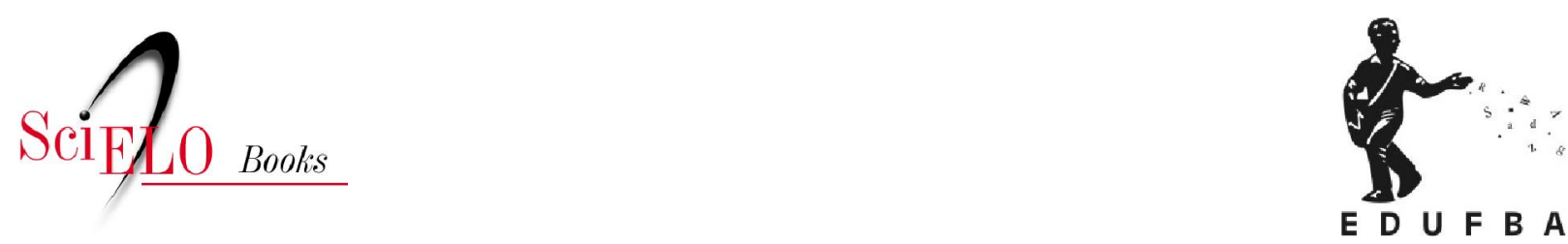

\title{
A arena e as regras
}

\author{
Silvia Noronha Sarmento
}

\section{SciELO Books / SciELO Livros / SciELO Libros}

SARMENTO, S. N. A arena e as regras. In: A raposa e a águia: J.J. Seabra e Rui Barbosa na política baiana da primeira república [online]. Salvador: EDUFBA, 2011, pp. 55-98. ISBN 978-85-232-11530 . Available from: doi: $10.7476 / 9788523211530.004$. Also available in ePUB from: http://books.scielo.org/id/ykf8q/epub/sarmento-9788523211530.epub.

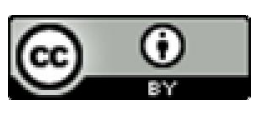

All the contents of this work, except where otherwise noted, is licensed under a Creative Commons Attribution $\underline{4.0 \text { International license. }}$

Todo o conteúdo deste trabalho, exceto quando houver ressalva, é publicado sob a licença Creative Commons Atribição 4.0.

Todo el contenido de esta obra, excepto donde se indique lo contrario, está bajo licencia de la licencia $\underline{\text { Creative }}$ Commons Reconocimento 4.0. 


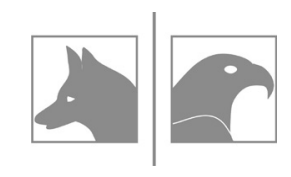

\section{AARENA E AS REGRAS}

\section{A Bahia de Rui e Seabra}

A República inaugurou uma nova dinâmica política no Brasil. A antiga tensão entre centralização e poder local, presente desde a colônia, expressou-se, então, na adoção de um modelo de federalismo articulado principalmente em torno das províncias, transformadas em estados. Aprofundava-se uma tendência, visível desde o Ato Adicional (1834), de submissão do poder local a um arranjo político regionalizado, processo intensificado com a extinção dos mecanismos centralizadores do Império (partidos nacionais, nomeação dos presidentes de província, Poder Moderador). ${ }^{1} \mathrm{O}$ federalismo resultou no fortalecimento dos grupos que dominavam o poder estadual, que se tornaram atores fundamentais do jogo político nacional. ${ }^{2}$

1 Sobre o processo de fortalecimento das elites provinciais, mesmo na vigência das medidas centralizadoras do Império a partir de 1840, ver Dolhnikoff (2003). Acerca da persistente tensão entre centralismo e regionalismo no Brasil, ver os estudos de Israel Pinheiro.

2 A visão do federalismo republicano adotada neste trabalho apoia-se nos estudos de Cláudia Viscardi (2001), que renovaram a compreensão do jogo político na Primeira República. A autora questionou a antiga tese de uma aliança estável e duradoura entre São Paulo e Minas Gerais (a "política do café com leite") chamando a atenção para a complexidade dos arranjos políticos do período. Nesse novo panorama, aparecem como atores principais, não 
Muito cedo, os baianos perceberam que estavam em desvantagem nesse novo jogo. Não que a Bahia não tivesse relevância política na República. Com a segunda maior bancada do Congresso (menor apenas do que a de Minas Gerais e igual à de São Paulo) e o peso da antiga tradição, os dirigentes estaduais ainda tinham um espaço importante nas negociações nacionais. Porém, em comparação com a situação privilegiada do Império, era evidente o declínio.

Ao longo das quatro décadas da Primeira República, a Bahia teve apenas um representante na presidência, e ainda assim, de forma temporária: Manuel Vitorino, que assumiu o cargo por motivo de doença do titular, Prudente de Morais. Somente em 1930, outro baiano (Vital Soares) seria elevado novamente à vice-presidência, mas não tomaria posse devido à revolução ocorrida naquele ano. Nos ministérios republicanos, a presença da Bahia foi discreta, em comparação ao Império: entre 1889 e 1930, apenas treze baianos foram nomeados ministros (Tabela 1 ), sendo seis militares em pastas relacionadas à defesa e às relações exteriores. Dentre os ministros civis, cuja escolha refletia mais claramente o poder estadual (já que a escolha dos militares atendia também a questões internas da corporação), dois foram interinos. Restam cinco nomes: Rui Barbosa, Seabra, Severino Vieira, Miguel Calmon e Otávio Mangabeira, que exerceram influência nacional nas primeiras décadas republicanas.

somente os estados mais poderosos (São Paulo, Minas Gerais, mas também Rio Grande do Sul, Bahia, Pernambuco e Rio de Janeiro), como ainda outros agentes dotados de certa autonomia, como o Exército e o próprio Estado Nacional. 
Tabela 1 - Ministros baianos na Primeira República (1889-1930)

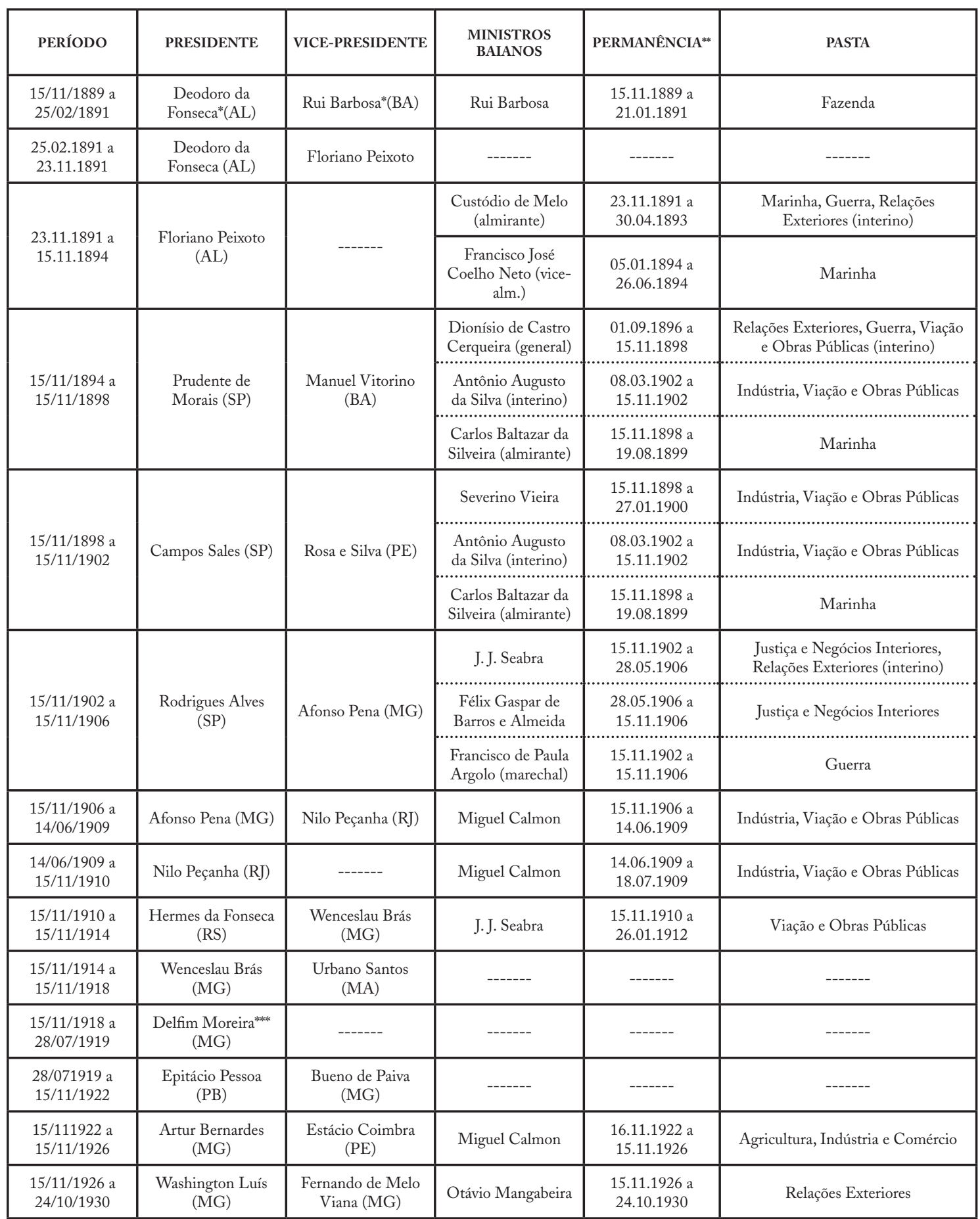

Fonte: Tabela elaborada com dados do site da Presidência da República: www.presidencia.gov.br.

Deodoro da Fonseca e Rui Barbosa, no período inicial da República, não tinham o cargo de presidente e vice-presidente, mas de chefe e vice-chefe do governo provisório.

** Quando o ministro ocupar mais de uma pasta, o tempo de permanência refere-se ao início e fim de sua participação no ministério, sem discriminar por pasta.

*** O vice-presidente Delfim Moreira assumiu o cargo até a realização de novas eleições porque o presidente eleito Rodrigues Alves faleceu antes da posse. 
Grífico 1. Comércio Exterior da Bahia (1840-1930)

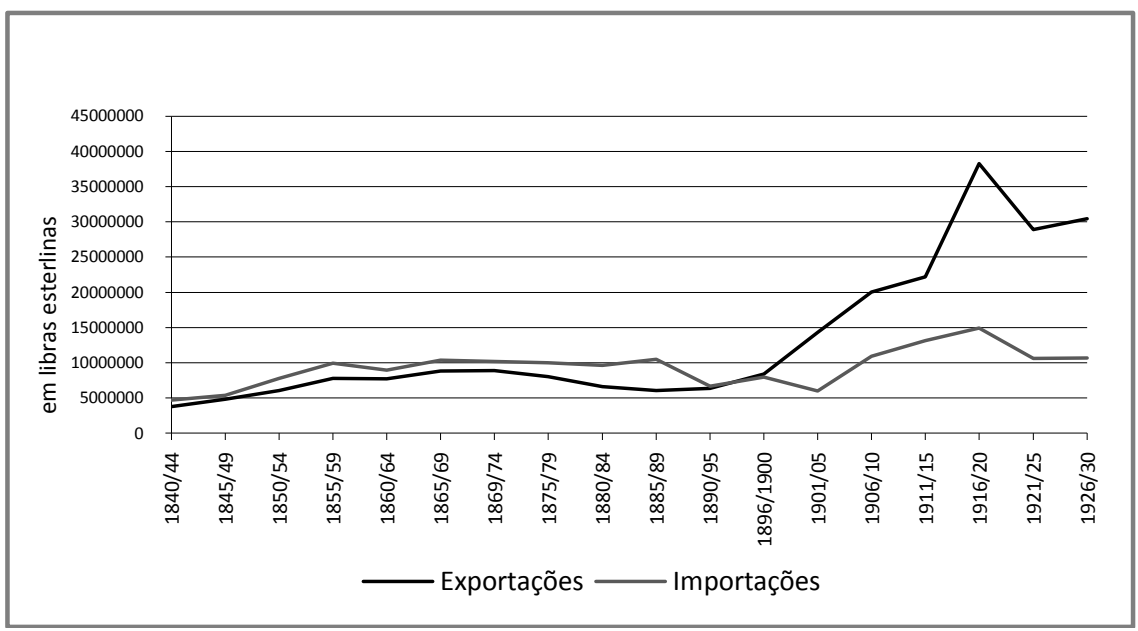

Fonte: Gráfico elaborado a partir de dados de FUNDAÇÃO CENTRO DE PESQUISAS E ESTUDOS, 1980, p. 113 (tabelas 5 e 6).

Grífico 2. Valor da Produção Agrícola em 1920 (em mil réis)

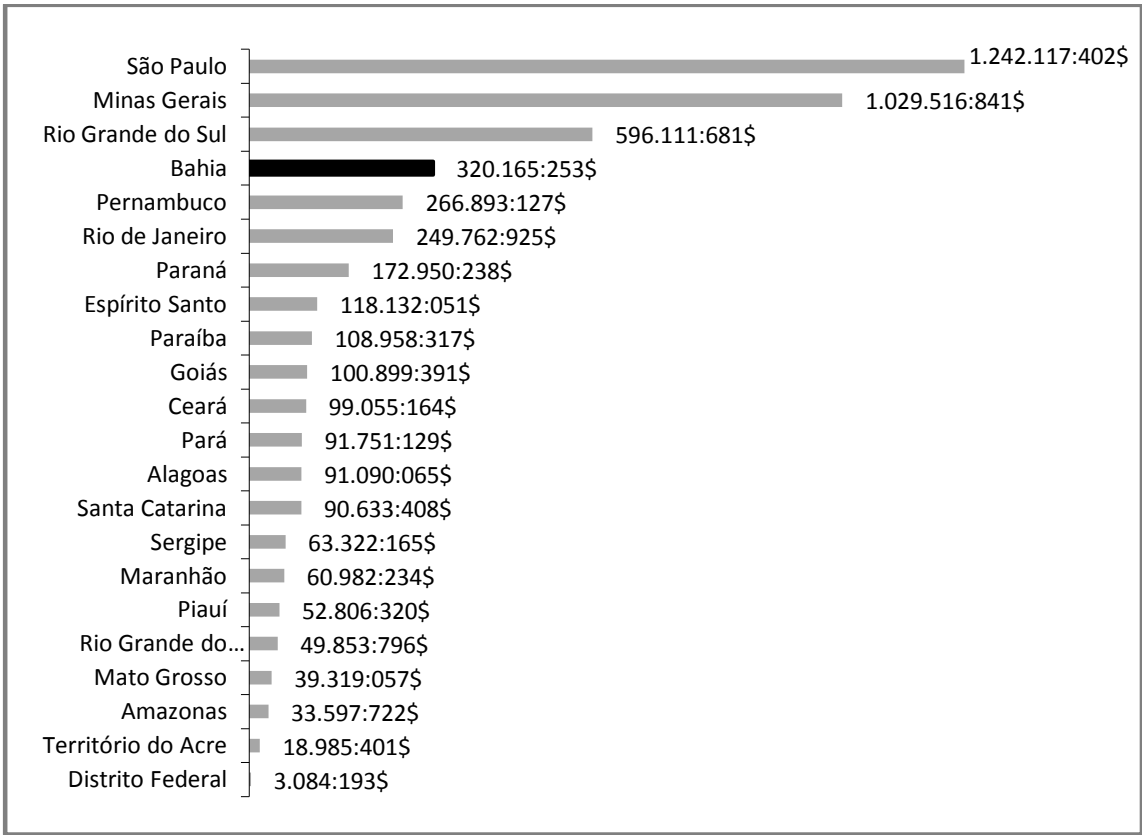

Fonte: BRASIL. Ministerio da Agricultura, Industria e Commercio. Censo de 1920. v. 5, p. 139. 
Grífico 3. Participação da Bahia nas Exportações Brasileiras (1889-1930)

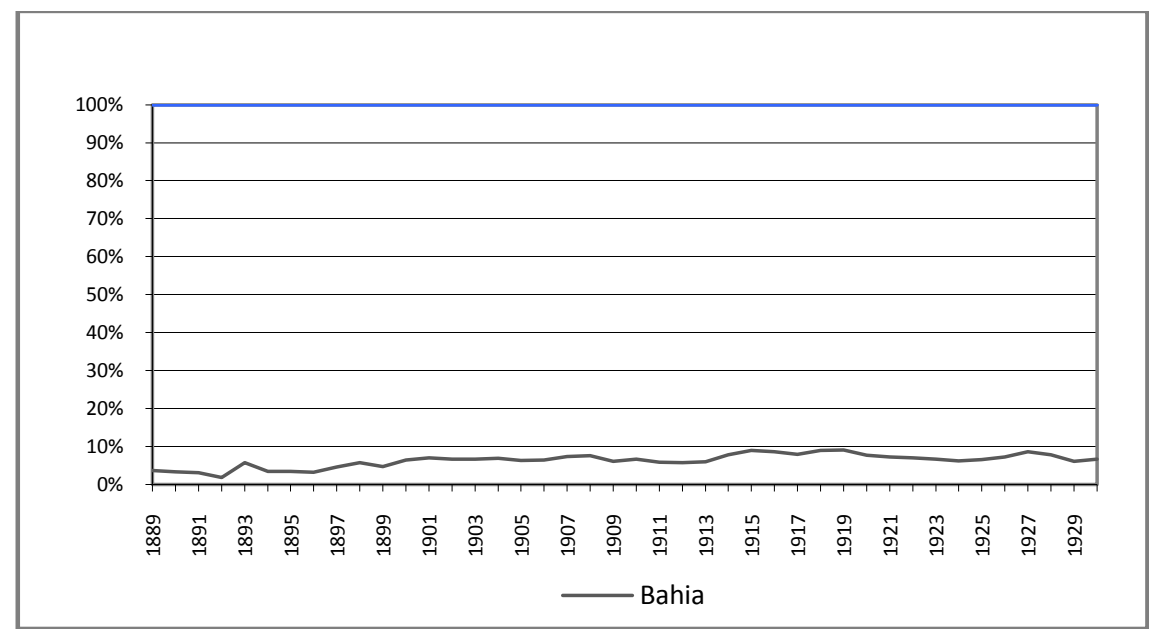

Fonte: Gráfico elaborado a partir de dados de FUNDAÇÃO CENTRO DE PESQUISAS E ESTUDOS, 1980, p. 121 (tabela 17).

Grífico 4. Valor da Produção Industrial em 1920 (em mil réis)

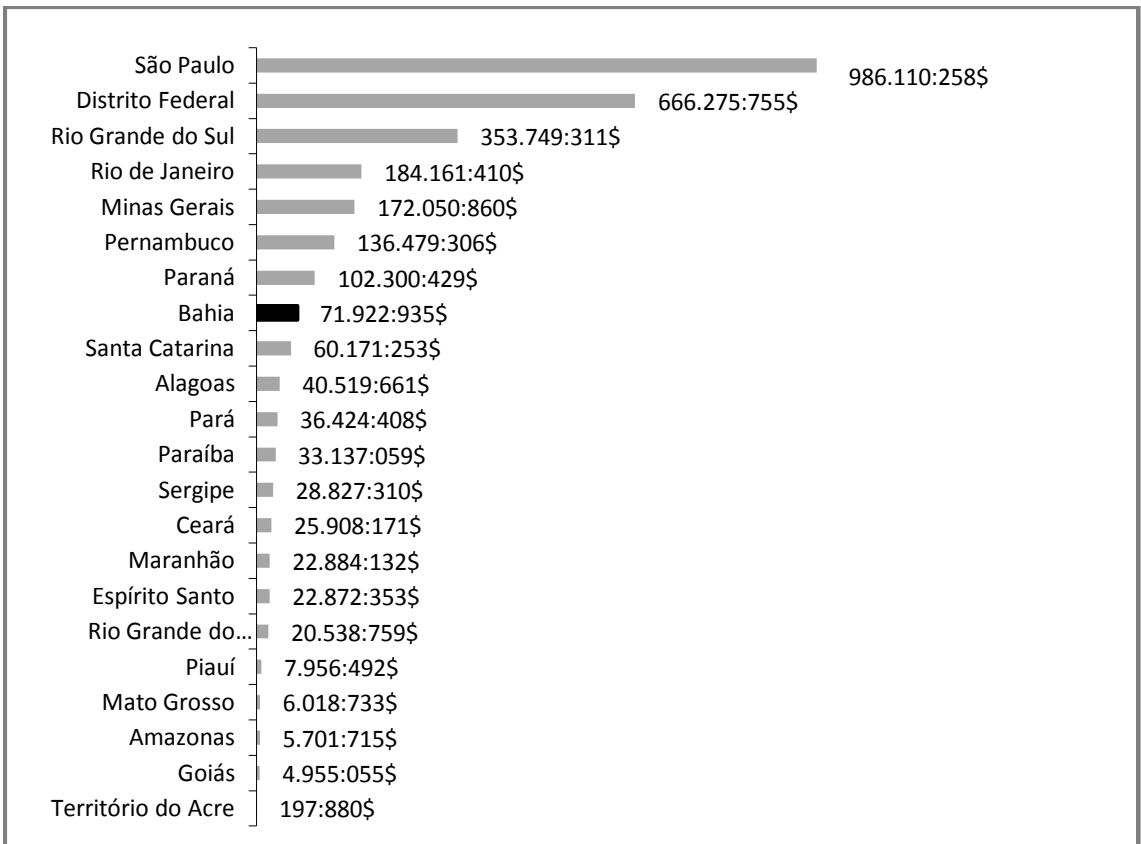

Fonte: BRASIL. Ministerio da Agricultura, Industria e Commercio. Censo de 1920, v. 4, p. 54. 
Em termos econômicos, apesar do grande sucesso do cacau, que contribuiu para o aumento das exportações em relação ao Império (Gráfico 1), a Bahia não podia se comparar à pujança dos estados cafeeiros. Em média, as exportações baianas contribuíram com apenas 6,72\% do valor total das exportações brasileiras no período, atingindo o máximo de 9,95\% em 1919 (Gráfico 3). Considerando-se que a exportação de produtos tropicais era o principal norteador da economia brasileira, entende-se que o peso econômico da Bahia era pouco expressivo. Essa avaliação se mantém quando se considera também a produção para consumo interno, o que se fez utilizando dados do censo de 1920. Naquele ano, apesar da produção agrícola da Bahia (incluindo itens de consumo interno, como feijão e gado) ser a quarta mais valiosa do país, seu valor correspondia a pouco mais de $25 \%$ da produção paulista (Gráfico 2). No caso da produção industrial, o quadro é ainda mais modesto: a Bahia, pioneira da indústria brasileira no século XIX, aparece no censo de 1920 em um discreto oitavo lugar (Gráfico 4).

A perda de importância política, somada à fragilidade econômica, despertou um sentimento de desconforto nas elites baianas. A Bahia de tantas tradições, mãe do Brasil, celeiro de estadistas, berço da civilização brasileira, era agora humilhada e destratada, considerada terra do atraso, do “já teve". (LEITE, 2005) Esse sentimento perpassa o imaginário político da Bahia republicana. Os governantes sucessivamente prometiam retomar o lugar que pertencia à Bahia "por direito", dentre os grandes estados da Federação brasileira - esse discurso foi especialmente fortalecido durante o período de domínio seabrista.

$\mathrm{Na}$ República, ao contrário do que ocorria no Império, os governadores passaram a ser eleitos, o que levou ao desenvolvimento de uma complexa dinâmica política entre os poderosos locais e aqueles que controlavam o governo estadual. Trata-se, em linhas gerais, do quadro desenhado por Vítor Nunes Leal (1997), em seu clássico estudo sobre o coronelismo: os mandões locais, ou "coronéis", forneciam os votos que

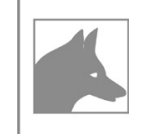


simbolizavam o controle da população à sua volta e, em troca, os governantes da capital nomeavam gente dos mesmos "coronéis" para os cargos que representavam a presença do Estado nos municípios (polícia, justiça, fisco, escola, entre outros), o que consolidava ainda mais o domínio do "coronel" na localidade. ${ }^{3}$

Ocorre que, em vários municípios, não havia apenas um "coronel", mas vários chefes disputando o poder. Da mesma forma, diversos grupos lutavam pelo controle do governo estadual. Essas forças se compunham em arranjos dinâmicos. A cada eleição, um novo conjunto de forças se sobrepunha às demais, e os derrotados engrossavam as fileiras da oposição.

O alistamento de eleitores, a divisão das seções, a composição das mesas, a elaboração das atas, a apuração, tudo isso se fazia sob as vistas daqueles que controlavam o governo municipal. ${ }^{4}$ Os resultados eram enviados à instância competente do Poder Legislativo (municipal, estadual ou federal), que "verificava" os votos e "reconhecia" os eleitos. A possibilidade de mudar os resultados no "reconhecimento" fazia com que os grupos dominantes nos estados e no país não ficassem reféns dos votos produzidos no nível municipal. Caso fosse necessário, os deputados e senadores governistas (que eram sempre maioria, pois o próprio governo os elegia) anulavam a eleição ou modificavam números. Essas "retificações", também chamadas de "degolas", sempre causavam certo desgaste

3 O conceito de "coronel", apesar de sua popularidade, é cercado de divergências na historiografia. (CARVALHO, 1997) No que concerne a este trabalho, entenda-se que se trata de um chefe politicamente ativo no meio rural, com domínio sobre uma territorialidade determinada, na Primeira República. Quando usado nesse sentido, o termo "coronel" será grafado com aspas, para diferenciá-lo do sentido estrito do título da Guarda Nacional. A preocupação se justifica porque nem todos os “coronéis" eram coronéis, e vice-versa. Um exemplo: o alfaiate Israel Ribeiro dos Santos, liderança operária de Salvador, adquiriu um título de coronel para marcar sua ascensão social. Mas, sua atuação política relacionava-se aos trabalhadores urbanos da capital, nada tendo a ver com os "coronéis" do interior. O inverso também ocorria: "coronéis" com título de doutor, por exemplo, mas que exerciam um mando tipicamente coronelista.

4 A partir de 1916, a apuração dos votos passou a ser feita sob a responsabilidade do juiz instalado no município, o que aumentou o controle do governo estadual, que nomeava os juízes, sobre as eleições. Ainda assim, se um juiz decidisse contrariar o poder local, precisaria estar amparado pela força policial do Estado, em contingente expressivo. Dificilmente, o governo teria condições de proporcionar esse amparo em todos os municípios, durante o processo eleitoral. A maioria dos juízes, assim, simplesmente referendava as decisões tomadas pelo poder local. 
político, por isso o mais comum era o acordo entre os grupos dominantes nos três níveis: municipal, estadual e federal.

Apesar da extinção do voto censitário, a riqueza ainda era um critério de cidadania presente na lei. A reforma eleitoral de 1904 (Lei Rosa e Silva) estabeleceu que, da comissão de alistamento, deveriam fazer parte obrigatoriamente os maiores contribuintes do município. Os homens mais ricos da região eram, assim, considerados os mais aptos para resolver as questões políticas. Esse mecanismo foi extinto pela reforma de 1916, mas a nova lei criou a obrigação de o eleitor provar que tinha meios de subsistência (renda ou atividade profissional considerada legítima) como condição para se alistar. A medida dava um caráter concreto à exclusão do voto dos "mendigos", prevista na Constituição de 1891. Também eram excluídos analfabetos, praças de pré (exceto aqueles que cursavam ensino superior, nítida distinção de classe social) e parte dos religiosos. A exclusão das mulheres não era explícita na legislação eleitoral, que nem sequer as mencionava, mas era vigente na prática.

Com todas essas restrições, além de critérios etários, o contingente máximo de brasileiros que podiam participar das eleições era bem inferior a $10 \%$ da população total. A participação efetiva era ainda menor. Os brasileiros aptos a votar tinham motivos para não exercer esse direito. Em primeiro lugar, a violência campeava no dia da eleição, com grupos armados prontos a sequestrar urnas, fechar seções, coagir eleitores e alterar atas, sob as ordens dos "chefes". Em segundo lugar, o valor do voto era diminuído pela generalização das fraudes e pelo próprio sistema de "verificação", que podia mudar os resultados nas instâncias superiores. Em geral, não era realmente para eleger alguém que se votava, mas para expressar apoio, nas relações de lealdade que sustentavam o sistema político da época.

As características do processo eleitoral, a violência e as fraudes favoreciam a continuidade dos mesmos grupos no poder. Em alguns estados brasileiros, a combinação desses mecanismos deu origem à instalação 
de verdadeiras dinastias no poder estadual. Esse é o sentido original das célebres “oligarquias" da Primeira República. O termo foi usado, inicialmente, como crítica aos arranjos familiares, como o domínio dos Malta, em Alagoas, e dos Acióli, no Ceará. Porém, em meio aos confrontos políticos, o sentido se ampliou, designando formas variadas de continuísmo e de autonomia exagerada do poder estadual. Tratava-se, no fundo, de uma crítica ao modelo de federalismo adotado na República, crítica que, em alguns casos, baseava-se no desejo de adoção de modelos centralizadores, como o que se implantou no país após 1930. A generalização da expressão "República Oligárquica" para designar o período histórico anterior ao movimento de 1930 está relacionada a essas referências. ${ }^{5}$

$\mathrm{Na}$ Bahia, os dirigentes republicanos nunca conseguiram criar um arranjo estável de controle do poder estadual. Essa instabilidade se explica por vários fatores. Em primeiro lugar, não havia a predominância de um único produto econômico na pauta estadual, como ocorria, por exemplo, em São Paulo, com o café, ou no Rio Grande do Sul, com o gado. A Bahia entrou na República com uma economia diversificada, com destaque para quatro produtos: açúcar, café, fumo e cacau. Apesar de ter se tornado o principal produto baiano já em 1902, foi a partir da década de 1920 que o cacau começou a se destacar significativamente dos demais (Gráfico 5). Até então, havia um relativo equilíbrio, que dificultou a formação de um grupo com interesse comum que conseguisse monopolizar o controle do Estado. (SAMPAIO, 1998)

\footnotetext{
5 Oligarquia é, literalmente, governo de poucos, mas seu sentido nunca se limitou a isso. Desde os gregos, o termo já trazia uma carga negativa: designava um governo de poucos e maus, um governo viciado. Era mais uma palavra de combate político, algo que se atribuía aos adversários, do que um conceito. Nesse sentido, contrapunha-se mais à aristocracia (também governo de poucos, mas dos melhores) do que à democracia. (BOBBIO, 2000) Para uma excelente revisão do sentido histórico do termo "oligarquia”, ver Dantas (1996).
} 


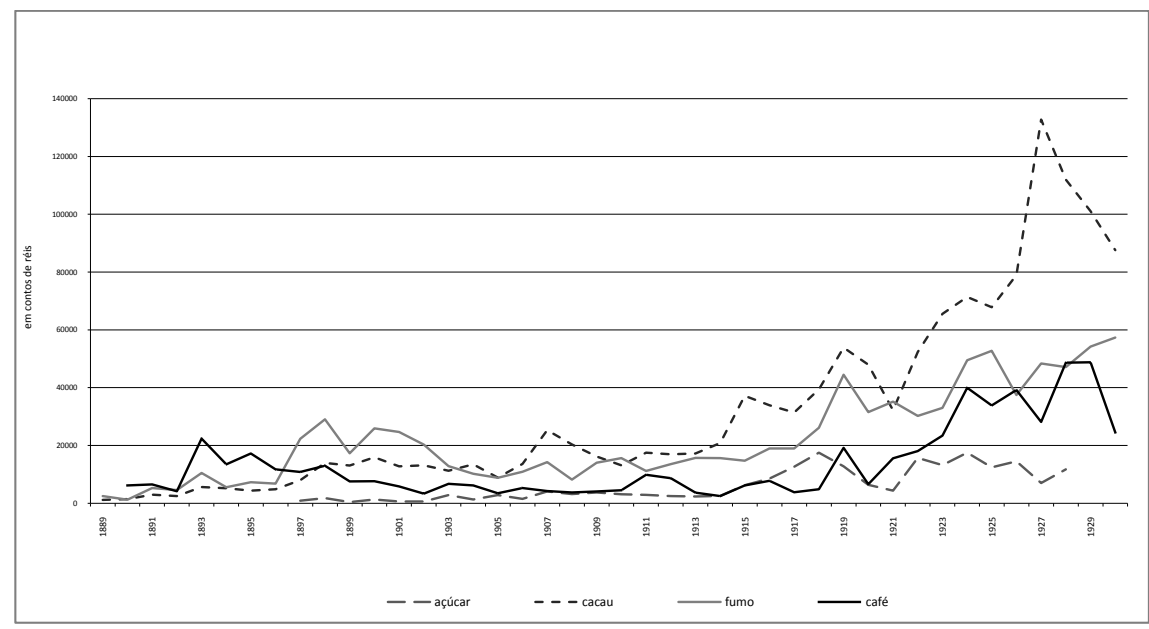

Fonte: Gráfico elaborado a partir de dados de Fundação Centro de Pesquisas e Estudos, 1980, p. 110 (tabela 3).

* Gráfico elaborado com "valor oficial" da exportação anual dos produtos, não se considerando o "valor de bordo", citado na tabela de origem.

Outro fator que contribuía para a instabilidade política era a deficiência do controle do governo estadual sobre a totalidade do território, que se relacionava, por um lado, à falta de transportes rápidos para grande parte do interior, e, por outro, à fragilidade da força policial. No tocante aos transportes, com a exceção da ferrovia de Salvador a Juazeiro e da ferrovia Central da Bahia, a expansão ferroviária ficou limitada a uma área relativamente próxima da capital e do Recôncavo. Extensas áreas do território, incluindo alguns dos municípios mais populosos, continuavam acessíveis somente por rios e caminhos de terra (Figura 1). Quanto à polícia, a Bahia contava com um contingente pequeno, mal armado e mal treinado em comparação a outros estados. (LOVE, 1975; SAMPAIO, 1998) Tudo isso favorecia uma maior autonomia dos poderes locais. Como o governo estadual poderia controlar chefes guerreiros, como os "coronéis" da Chapada Diamantina, com uma força policial acanhada e dificuldades de acesso?

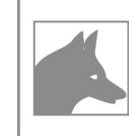


A instabilidade política se expressava claramente na fragilidade dos partidos baianos (Figura 2). Eram frequentes as cisões e rearrumações, em uma dinâmica que Consuelo Novais Sampaio (1998) chamou de "política de acomodação". A partir de Luís Viana, que rompeu com o antecessor José Gonçalves, em 1891, cada governador brigou com o anterior até a ascensão de Seabra, em 1912. A única exceção foi Araújo Pinho, que não chegou a romper com José Marcelino, mas que acabou abandonando o governo antes do fim, sob pressão dos seabristas.

O governador era a figura central da dinâmica política estadual. O processo de sua eleição seguia a lógica do continuísmo, vigente em toda a República: o governador em exercício escolhia um nome que supunha ser bem aceito pelas forças que apoiavam seu governo (o que, muitas vezes, desagradava a alguns grupos, que podiam ser deslocados para a oposição). Mesmo quando a oposição lançava um candidato, o governista costumava ser eleito, pois o governo, além de ter o controle da máquina administrativa (nomeações/demissões), normalmente tinha maioria na Assembleia Legislativa, responsável pelo processo de "verificação de poderes". Em uma situação de controle político, não seria necessário sequer adulterar os resultados na apuração, pois o apoio dos chefes mais poderosos era suficiente para prover uma maioria incontestável de votos. Todos os envolvidos no processo sabiam que os votos não representavam, em realidade, a vontade da população. Eles simbolizavam o apoio dos "amigos", como se costumava dizer, além de indicar a força de cada chefe em sua região. Quanto mais votos o "coronel" enviasse para a capital, não importando os meios usados para obtê-los, mais forte esse chefe se mostraria diante dos olhos do governo, que se esforçaria para mantê-lo como aliado. 


\section{Figura 1. Mapa esquemático de municípios e ferrovias da Bahia}

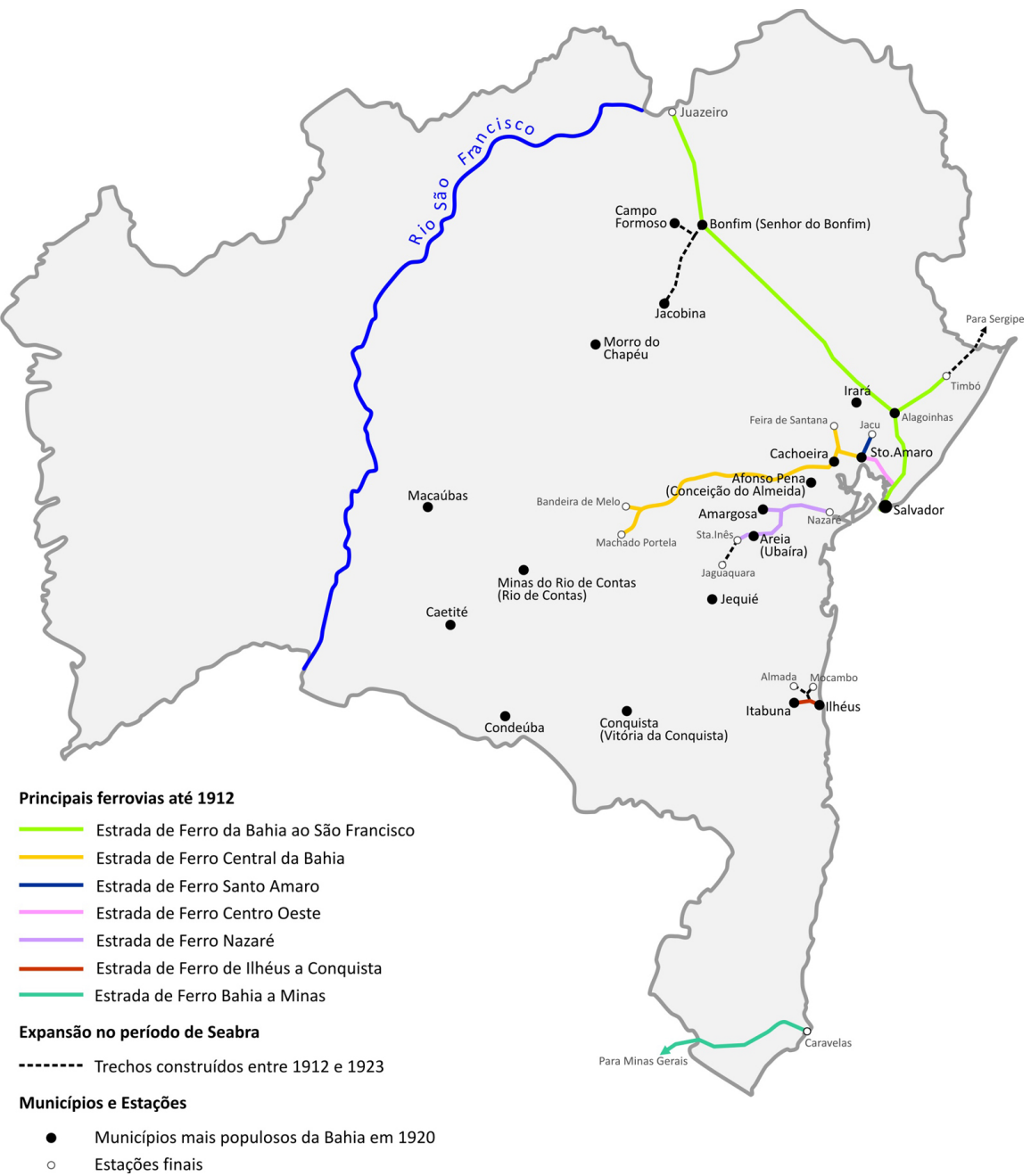

Fonte: Mapa elaborado a partir de dados compilados de: BAHIA. Governador (J. J. Seabra). Mensagem apresentada à Assembleia Legislativa da Bahia. Bahia: Tipografia da Revista do Brasil, 1912; BRASIL. Ministério de Viação e Obras Públicas. Relatório apresentado ao Presidente da República dos Estados Unidos do Brasil pelo Ministro de Estado da Viação e Obras Públicas Dr. J. J. Seabra. Rio de Janeiro: Imprensa Nacional, 1911; FREITAS, A. F. G. Au Brésil: Deux Regions de Bahia (1896-1937). Tese (Doutorado) - Universidade de Paris IV Sorbonne. Paris, 1992. E também do site <www.estacoesferroviarias.com.br>. Acesso em: 10 jul. 2008; SUPERINTENDÊNCIA DE ESTUDOS ECONÔMICOS E SOCIAIS DA BAHIA. Mapa divisão administrativa da Bahia. Disponível em: <www.sei.ba.gov.br/>. Acesso em: 11 jul. 2008; DIÁRIO OFICIAL DO ESTADO DA BAHIA. Versão digitalizada da Edição Especial do Centenário da Independência Política do Brasil na Bahia (1823-1923). Salvador: EGBA/Fundação Pedro Calmon, 2007. 
Figura 2. Diagrama dos partidos políticos da Bahia na Primeira República

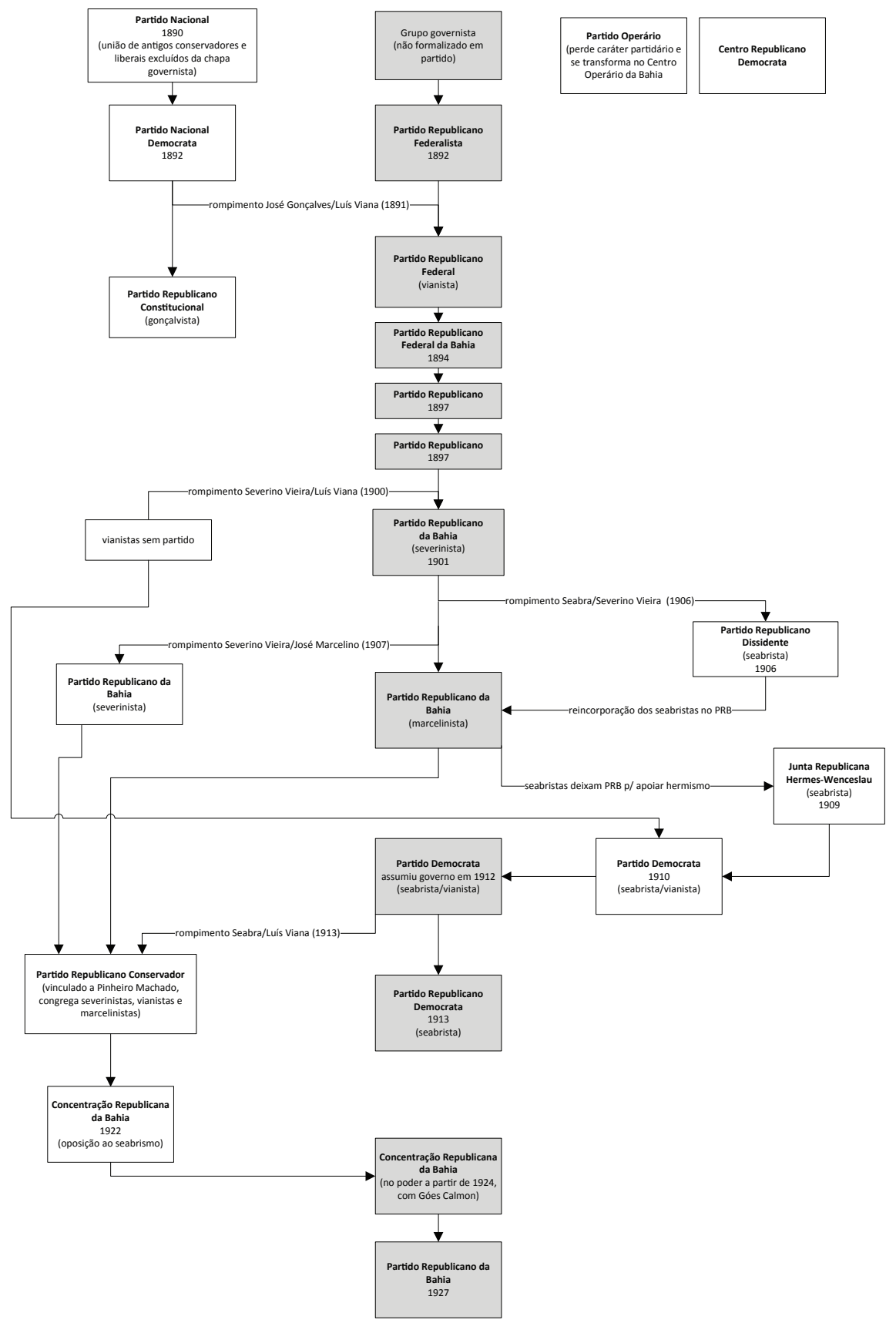

Fonte: Diagrama elaborado a partir de informações de Sampaio (1998).

*Foram marcados em cinza e situados ao centro do gráfico os partidos que ocupavam o governo da Bahia. 
$\mathrm{Na}$ Bahia, devido à constante instabilidade política, nunca se podia ter certeza de que o novo governador iria se manter fiel ao anterior. Os oposicionistas pressionavam por uma ruptura, certos de que seria sua chance de aderir ao governo. Muitas vezes, essas rupturas aconteciam com apoio do governo federal, que era um ator fundamental na dinâmica estadual.

Apesar da mística da "política dos governadores" de Campos Sales, que pretendia proporcionar estabilidade ao regime pela garantia da autonomia estadual, o fato é que o governo federal interferiu na política baiana diversas vezes, ao longo da Primeira República. A primeira ação ocorreu ainda no governo Floriano Peixoto (antes de Campos Sales, portanto), com a deposição do governador deodorista José Gonçalves, o que deu ensejo à reação imediata de Rui Barbosa. A segunda interferência, porém, ocorreu com apoio de Rui, em 1907, quando o presidente Afonso Pena apoiou a facção do governador José Marcelino, em disputa eleitoral contra o grupo de Severino Vieira. Os severinistas tinham maioria na Assembleia Legislativa Estadual, responsável pela “verificação” dos votos, mas os marcelinistas tinham o controle do governo e de sua polícia. Segundo os severinistas, a polícia estadual cercou o prédio da Assembleia e forçou a apuração favorável ao governo. $\mathrm{O}$ apoio do poder federal foi decisivo para a aceitação desses resultados. Novas interferências na política da Bahia, mais explícitas e violentas, ocorreram em 1912, 1919 e 1924. Todas elas serão abordadas mais adiante.

Além do governo federal, a política baiana também estava sujeita à interferência de políticos de outros estados, especialmente no Congresso Nacional, onde ocorria a "verificação" das eleições federais. Pode-se citar, como exemplo, a atuação do senador gaúcho Pinheiro Machado, que chegou a chefiar as oposições baianas, como se verá no terceiro capítulo.

$\mathrm{Na}$ interface com a política nacional, concentrava-se a atuação de Rui Barbosa e Seabra no início da República. Ambos moravam no Rio de Janeiro, onde tinham seus escritórios de advocacia. Como membros 
da bancada baiana no Congresso, eles deveriam representar a política do seu estado nas negociações nacionais. Porém, no caso de Rui e Seabra, isso nem sempre aconteceu. Já se observou que Rui fez oposição a todos os presidentes da República entre 1891 e 1901. Ora, isso não correspondia à posição oficial do governo baiano, que, não só apoiava os governos federais, como se esforçava para inserir baianos nos ministérios. Enquanto Rui combatia Campos Sales, por exemplo, Severino Vieira ocupava o ministério da Viação como representante do situacionismo baiano, com o qual Rui se dizia solidário. Era uma situação atípica na República, só explicada pelo excepcional prestígio de Rui.

Quanto a Seabra, apesar de ter conseguido seus primeiros mandatos de deputado federal graças a articulações na Bahia, sua atuação no Congresso Nacional se deu mais em relação pessoal com o poder federal, do que por delegação da política baiana. Foi pela ação individual que ele se destacou, conquistando apoios para ser nomeado ministro, em 1902, sem que o governador da Bahia (Severino Vieira) fosse sequer consultado.

De fato, Seabra nunca logrou obter o apoio dos chefes estabelecidos da Bahia para seus planos políticos. Pelos meios ordinários, dificilmente conseguiria se tornar governador. Talvez por causa de suas atitudes ousadas, não inspirava confiança nos chefes tradicionais. Nesse sentido, como analisa Cid Teixeira (apud LiNs, 1988, p. 43), ele era realmente "um corpo estranho dentro daquilo que estava programado na sociedade baiana para chegar ao poder". Sua ascensão ao governo estadual deveria ocorrer, assim, em condições excepcionais.

No primeiro capítulo, já se viu como Seabra procurou compensar sua falta de bases na política estadual através da atuação nacional. Como ministro, a partir de 1902, ele teria a oportunidade de formar seu próprio agrupamento político no estado. Sua atitude não foi inicialmente belicosa. Seabra buscou se apresentar como um elemento forte, passível de ser indicado para a sucessão estadual dentro dos processos do continuísmo vigentes. Tentou cooptar o governador de então, José Marcelino, 
instando-o a romper com o antecessor, Severino Vieira, que era também chefe do Partido Republicano da Bahia (PRB), o que não ocorreu naquele momento. Diante disso, Seabra foi levado a romper com o governo estadual em 1906. Por seu pouco enraizamento na política baiana, ele buscou agregar ao seu grupo elementos relativamente negligenciados nos embates políticos até então, especialmente o comércio e os trabalhadores de Salvador, cujo apoio poderia legitimar suas pretensões.

Salvador ingressou no século XX como a terceira cidade mais populosa do país. Era a segunda até a década de 1890, quando foi ultrapassada por São Paulo, que vinha em impressionante ritmo de crescimento. A maior cidade brasileira era o Rio de Janeiro, capital federal, também em franca expansão. Na década de 1920, o Rio atingiria seu primeiro milhão de habitantes. O ritmo de crescimento de Salvador era mais modesto: sua população permaneceu praticamente estável na Primeira República, com pequena expansão por crescimento vegetativo. (SANTOS, 2001, p. 14) Ainda assim, a capital baiana era a terceira maior aglomeração urbana do país, com cerca de 280 mil habitantes em 1920. (BRASIL, 1922)

Por seu contingente populacional e pela concentração de comércio, indústria e serviços, a capital tinha uma vida urbana mais complexa do que as demais cidades baianas, com maior diversidade de atividades econômicas. Além de pessoas dedicadas a atividades rurais, nas roças, estábulos e chácaras que ainda faziam parte de sua paisagem, Salvador tinha uma quantidade expressiva de trabalhadores desvinculados do setor primário: operários da construção civil, alfaiates, padeiros, estivadores, costureiras, motorneiros de bonde, funcionários públicos, sapateiros, vendedores ambulantes, caixeiros, operários das fábricas de tecidos, de cigarros, de chapéus, das fabriquetas de alimentos e bebidas, de velas, de sabão, trabalhadores domésticos, entre muitos outros, além de uma infinidade de biscateiros, dispostos a enfrentar qualquer trabalho não especializado na luta pela sobrevivência diária. (SANTOS, MÁRIO, 2001) 
A parcela mais qualificada e socialmente valorizada desses trabalhadores vinha demonstrando interesse em participar da política partidária da Bahia desde o início da República. A fundação do Partido Operário, em 1890, é uma evidência disso. Esse partido, entretanto, teve vida curta e foi extinto em 1893, dando origem ao Centro Operário da Bahia. A transformação do partido em uma entidade sem fins políticos se relaciona à dificuldade que seus membros encontraram em furar o bloqueio dos partidos dominantes, dos "chefes" tradicionais, herdeiros dos senhores do Império. Era simplesmente impossível, no contexto da Primeira República, ser eleito sem o apoio de quem estivesse no poder. Apesar de contar, entre seus quadros, com elementos da elite, como alguns donos de fábrica, o Partido Operário não conseguiu encontrar um espaço de atuação política. Diante disso, os líderes desse segmento qualificado do operariado de Salvador adotaram outra estratégia. (CASTELLUCCI, 2008)

Em lugar de insistir na atuação autônoma, os membros do Centro Operário da Bahia estreitaram laços com indivíduos já inseridos na política dominante, veiculando, através deles, as propostas que julgavam prioritárias, segundo os interesses dos trabalhadores que representavam. Essa não era uma postura estranha ou incomum naquele contexto. Como analisa Aldrin Castellucci (2008), a estratégia relaciona-se à antiga tradição das associações beneficentes e irmandades do século XIX, que aclamavam seus patronos dentre os homens mais ricos e poderosos da sociedade, em condições de thes proporcionar benefícios diversos.

Para os beneméritos das irmandades e associações do Império, o retorno era de prestígio, já que ser caridoso e magnânimo com os humildes ressaltava a própria superioridade social. Mas, no caso da Primeira República, havia outros elementos em jogo. Além dos votos, a aproximação dos operários proporcionava a legitimidade advinda do apoio de uma das classes reconhecidas como integrantes do "edifício social", embora em posição inferior (ou seja, na base, nos alicerces). Trata-se de uma mudança sutil, mas visível no discurso dos políticos dominantes da República. 
Operários, apesar de subalternos, não eram iguais a escravos. Eles tinham um lugar na sociedade moderna e civilizada que se desejava construir. A questão era como fazer com que eles ficassem quietos, obedientes, em seu lugar. Os distúrbios nos alicerces eram perigosos, pois poderiam fazer desmoronar todo o edifício da ordem.

Em troca do apoio a esses políticos, os líderes do Centro Operário conseguiam várias vantagens: recursos financeiros, em forma de subvenções para a entidade; apoio para aprovação de leis e outros projetos de interesse dos trabalhadores; eleição de representantes próprios, geralmente para cargos municipais, como conselheiros e juízes de paz. Esses eram os cargos mais altos que se costumava admitir para alguém proveniente do operariado, pois o acesso aos postos políticos mais valorizados permanecia restrito ao universo dos senhores. Além desses benefícios gerais, a associação com políticos fortes no panorama estadual era uma arma importante nas disputas internas da instituição. (CASTELLUCCI, 2008)

Em 1903, por exemplo, durante uma disputada eleição para a presidência da entidade, o grupo do operário da construção civil Domingos Silva pediu ajuda ao ministro Seabra, em uma tentativa de igualar o jogo diante dos adversários, liderados pelo alfaiate Ismael Ribeiro dos Santos, que tinham apoio do governo estadual. Situação ainda mais tensa foi vivida em 1911, quando nada menos do que três grupos, cada um deles associado a um político (Seabra, Severino Vieira e José Marcelino) reivindicava a presidência do Centro Operário. O impasse levou à existência de uma "triplicata" de poderes, com cada grupo tomando posse em uma sede diferente, como se fosse o único Centro Operário da Bahia. ${ }^{6}$ (A BAHIA, 20 maio 1911)

\footnotetext{
6 O fenômeno das "duplicatas" de poderes consistia no seguinte: diante dos vícios costumeiros do processo eleitoral, os dois lados em disputa proclamavam-se eleitos e tomavam posse em edifícios diferentes. Isso ocorreu três vezes com o Poder Legislativo baiano, em 1895, 1915 e 1923. Na duplicata de 1915, as duas Câmaras estaduais funcionaram independentemente durante todo o período legislativo. (SAMPAIO, 1998, p. 128) A "triplicata" do Centro Operário mostra, portanto, um interessante paralelismo com os processos políticos dos partidos tradicionais.
}

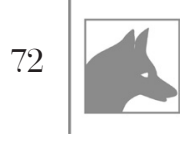


Havia, ainda, outro segmento social na cidade de Salvador que merecia as atenções especiais dos políticos da Primeira República: o comércio. Tradicionalmente, a Associação Comercial da Bahia, porta-voz dos maiores comerciantes do estado, dizia não se envolver em política. Mas, como observa Mário Augusto Silva Santos (1991), ela atuava politicamente o tempo todo, funcionando como um "grupo de pressão". Desde 1902, a Associação Comercial vinha se relacionando com o então ministro Seabra, pedindo seu apoio para as questões de interesse das chamadas "classes conservadoras" 7 . Em 1912, alguns dos seus dirigentes se engajaram no movimento que resultou na ascensão de Seabra ao governo estadual. Porém, o relacionamento dos comerciantes com o seabrismo não foi muito duradouro. Em 1919, a Associação Comercial firmou compromisso com Rui Barbosa pela derrubada de Seabra. As oscilações refletem, não somente as tensões políticas externas, como as questões internas da instituição. Além de mudanças estruturais, a ascensão de diretorias vinculadas a este ou aquele político dominante, pleitos atendidos ou rejeitados e outras conveniências diversas marcaram a dinâmica da atuação política da entidade.

Os votos angariados com apoio dos comerciantes e industriais, como também dos operários da capital, não parecem ter sido o motivo principal para que políticos como Seabra e Rui Barbosa a eles recorressem. Mesmo que esses setores fornecessem grande quantidade de votos, isso ainda não seria suficiente para desmontar o mecanismo das eleições fraudadas, com a conivência dos chefes do interior, que asseguravam a vitória do governo. Mas, o comércio e os trabalhadores de Salvador tinham uma visibilidade especial, expressa nos jornais e em certos rituais públicos. Eles forneciam uma legitimidade para o poder que, a partir da capital, se exercia sobre todo o estado. $\mathrm{O}$ apoio de parcelas significativas da população da capital poderia,

\footnotetext{
A expressão "classes conservadoras" é extremamente recorrente em discursos públicos e jornais da Primeira República. Refere-se geralmente a três "classes": lavoura, indústria e comércio, que seriam as responsáveis pela conservação da ordem social. Muitas vezes, porém, a expressão "classes conservadoras" significa apenas o alto comércio, do qual a Associação Comercial era representante por excelência.
} 
inclusive, fundamentar uma "virada de mesa", justificando uma intervenção do governo federal - este, sim, era um poder capaz de subverter a lógica de continuidade estadual, no contexto da Primeira República.

Mas, como esses apoios e essa legitimidade se expressavam? Como eles eram contestados? Se a política exige sempre o acionamento de um repertório compartilhado de símbolos, quais eram os limites do território simbólico em que Rui e Seabra terçavam armas? Que regras regiam esses combates? Essas questões serão tratadas a seguir, com a abordagem de algumas características da retórica e dos rituais da Bahia republicana.

\section{Retórica e rituais políticos}

O que explica que, após debates de intensa violência verbal, adversários políticos como Rui e Seabra pudessem se reconciliar e estabelecer novas alianças? Como Rui pôde criar para Seabra a alcunha de Caim e ser chamado pelos seabristas de Anticristo, como se verá no terceiro capítulo, sem que isso significasse um rompimento definitivo entre eles?

A explicação parece residir nas características da retórica política usuais no início da República. Como aponta José Murilo de Carvalho (1999), no artigo "História intelectual: a retórica como chave de leitura”, a desqualificação do adversário era um recurso regular dentro desse campo discursivo. $\mathrm{O}$ autor informa que a tradição incorporada pelos letrados brasileiros do século XIX, visível nos compêndios educativos da época, remonta à retórica cívica romana, que incluía as qualidades morais do orador como critério de validação do discurso. O conteúdo do discurso era inseparável do valor do seu enunciador. Assim, o argumento "ad personam”, a agressão pessoal ao adversário, era, como é ainda hoje, um recurso usual no embate político.

Nos jornais baianos da Primeira República, a desqualificação encontrava o caminho da troça, resultando na criação de verdadeiras caricatu-

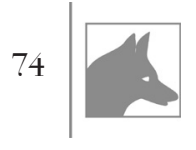


ras verbais. Era frequente, por exemplo, a criação de apelidos relacionados a animais, configurando uma espécie de "zoologia política". (MOREL, 1998) Severino Vieira, com seus olhos saltados, era o sapo-cururu; Araújo Pinho, considerado lento e antiquado, era a lesma de suiças; Virgílio de Lemos, chamado de porco pelos jovens seabristas (por causa do peso corporal), respondeu dizendo que eles eram os rafeiros (cães que ajudam na condução e vigia do gado) de Seabra. Para Muniz Sodré, provavelmente o seabrista mais hostil a Rui Barbosa, a célebre Águia de Haia não passava de um peru.

As agressões pessoais incluiam tudo que pudesse desvalorizar o adversário no campo político da época. Alguns, como Aurelino Leal, tiveram sua ascendência africana posta em cena. Outros sofriam alusões à sua sexualidade, honestidade, inteligência, vícios (bebida, jogo). José Inácio da Silva, político de Juazeiro, foi ridicularizado pelos primos Muniz Sodré e Antônio Muniz porque vinha de uma origem sertaneja e modesta. Em troca, ironizou os Munizes, muito ciosos de suas raízes aristocráticas, chamando-os de "fidalgotes de meia tigela". Arlindo Fragoso, secretário de Estado do primeiro governo Seabra, foi alvo de verdadeira campanha difamatória por parte de Simões Filho, que o acusava, entre outras coisas, de ser boêmio e andar com "cocotes" no carro oficial. O secretário entrou com processo na Justiça contra o jornalista, por calúnia.

É preciso observar, contudo, que nem todas as agressões eram toleradas. Alguns dos ofendidos decidiam "lavar a honra", o que dava margem a ocasionais atos de violência, como o que vitimou o tenente e deputado seabrista Propício da Fontoura, em 1918. Ele foi morto pelo jornalista Artur Ferreira, ligado à oposição ruísta, após confrontá-lo sobre artigos que considerou ofensivos à sua honra. Esse é apenas um exemplo de caso que extrapolou a dimensão política para invadir o terreno pessoal, com trágicas consequências.

A guerra de insultos era travada nas páginas dos jornais que representavam os grupos políticos. Mas, frequentemente, os confrontos escapavam do universo dos letrados se expandiam para o restante da 
população. Essa parece ser, inclusive, a força dos apelidos e das caricaturas (verbais ou gráficas): eles eram passíveis de serem entendidos e repercutidos mesmo por aqueles sem familiaridade com a leitura. Nas ruas, nas repartições públicas, nos cafés, nas casas comerciais, as pessoas comentavam os debates das gazetas. O inverso também ocorria, com expressões e zombarias populares sendo apropriadas pelos jornalistas em suas batalhas simbólicas. $\mathrm{O}$ mundo dos letrados e dos não escolarizados não era, de forma alguma, separado em compartimentos estanques. Havia circularidade cultural entre eles.

Como se registrou no primeiro capítulo, Rui e Seabra foram educados na segunda metade do século XIX, época em que os conhecimentos de retórica faziam parte, não apenas da formação do bacharel em Direito, mas até dos estudos preparatórios anteriores à faculdade. Eles estavam, pois, plenamente familiarizados com as regras do discurso vigentes. Eram ambos considerados excelentes oradores, embora seus estilos tivessem características distintas.

Rui Barbosa era, sem dúvida, a principal referência da retórica política brasileira da época. Seu estilo era estudado e copiado pelos jovens bacharéis, ávidos em repetir a sonoridade peculiar de suas frases, a sofisticação de suas construções verbais, a lógica demolidora de seus argumentos, amparados sempre por sólida erudição. Os longos e complexos discursos de Rui impressionavam mesmo a quem não entendia quase nada do que o grande orador estava dizendo. Nesse sentido, ele era uma "prodigiosa máquina de falar", na definição do conde de Afonso Celso. (SALDANHA, 1979, p. 168)

Com a passagem do tempo, e o surgimento de novos padrões estéticos, esse estilo rebuscado e "gongórico" (GONÇALVEs, 2000b) cairia em desuso. Mas, no início do século XX, os malabarismos verbais de Rui eram extremamente valorizados, pois eram a expressão perfeita dos modelos ensinados nas escolas e faculdades, como se pode verificar pela confrontação de seus textos com um dos livros didáticos que circulavam na época.

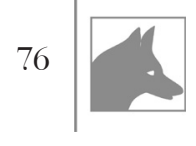


(FigueIREDo, 1875) Está tudo lá: a preocupação com a forma, o ritmo e a estrutura do texto, os neologismos o uso de repetições, gradações e aliterações, os tropos e as figuras de linguagem, a citação abundante de autores e exemplos estrangeiros como respaldo para as próprias ideias, entre outros elementos. Como exemplo, leia-se o artigo Caim, publicado em 1912, e reproduzido com comentários nos apêndices deste livro.

Seabra também era um orador renomado, mas enquanto Rui tinha como principal característica a sofisticação da estrutura de argumentação, o ponto forte da retórica seabrista era a elocução, a expressão oral. Com sua voz possante, retumbante, tão diferente da voz metálica e estridente de Rui, e seus gestos largos, teatrais - alguns o descrevem balançando freneticamente a mão direita enquanto discursava, outros, esmurrando a tribuna como ênfase - Seabra dominava os auditórios. Suas frases, apesar de bem construídas, não tinham a mesma riqueza vocabular e estilística das de Rui. Eram mais diretas, menos rebuscadas. Encantava menos o público letrado da época, mas, ao mesmo tempo, agradava mais os menos ilustrados, aos quais atraía com sua capacidade de comunicação oral, desenvoltura na apresentação e indiscutível carisma. Como observou Nelson Carneiro (1973, p. 23), Seabra era "um orador para ser ouvido".

Apesar das diferenças de estilo, tanto Seabra como Rui eram adversários temíveis na tribuna. Os dois tinham raciocínio rápido, presença de espírito e gosto por uma boa polêmica. Mais do que isso, ambos entendiam profundamente a função da retórica na vida de um homem público da época. Seus discursos não deviam apenas doutrinar e deleitar, mas também, e principalmente, mobilizar, mover para a ação. E, para isso, era necessário transcender a mera lógica e incluir no discurso uma carga de emoção, de paixão. Afinal, como ensina o manual de retórica consultado, "pelas provas, o orador instrui para convencer; pelas belezas, agrada para deleitar; pelos afetos, brandos ou fortes, move para persuadir”. (FIGUEIREDO, 1875, p. 4) 
A persuasão é especialmente importante porque a política não se faz apenas com palavras, escritas ou faladas. Ao lado da dimensão do "dizer", há também a do "fazer", dos rituais que afirmam solidariedades, que estabelecem publicamente a distinção entre quem está "dentro" e quem está "fora" de um grupo ou partido. (KERTZER, 2001) A Bahia republicana tinha uma variedade de rituais. Não serão abordados aqui rituais de caráter cívico-festivo, como as festas do Dois de Julho, mas apenas alguns rituais políticos em sentido estrito, ligados diretamente ao processo partidário e eleitoral. Eram momentos especiais do cotidiano em que certos aspectos da vida social e política eram dramatizados e ressignificados.

O comício ou meeting era provavelmente o mais aberto e espontâneo desses rituais políticos. Tratava-se, basicamente, de um ajuntamento de pessoas na rua para ouvir o discurso de um ou vários oradores. Os meetings podiam, ou não, ser programados com antecedência. Os dados disponíveis sugerem que, normalmente, não era preciso de autorização da polícia para promovê-los. Em 1918, quando o governador Antônio Muniz, em meio a uma grande crise política, decidiu proibir meetings em Salvador, os oposicionistas protestaram imediatamente contra a repressão à liberdade de expressão. Como o meeting ocorria em local aberto (ruas e praças, geralmente), era comum que elementos da plateia interrompessem os oradores com apartes, dando origem a bate-bocas acalorados, que podiam resvalar em violência generalizada.

Os meetings não eram exatamente uma novidade, pois vinham ocorrendo no Brasil pelo menos desde o século XIX. Na República, eles parecem ter se popularizado e multiplicado. Apareceram homens especializados em promover comícios, que eram chamados de "meetingueiros". Alguns dos meetingueiros tinham grau de bacharel, o que os habilitava a uma rápida ascensão política, caso seu grupo fosse vitorioso. Havia também meetingueiros de menor escolaridade, que nem sempre eram respeitados pela polícia. Afinal, um ajuntamento de pessoas 
do povo podia ser classificado pelas autoridades como "turba" ou "malta", não merecendo o respeito que o liberal meeting, com seus ecos ingleses, evocava. Apesar disso, o maior meetingueiro da Bahia não tinha estudo formal: era o rábula autodidata e major Cosme de Farias, figura de enorme popularidade em Salvador, e de quem ainda se voltará a tratar neste trabalho.

Em geral, os homens públicos de maior relevância, como governadores, senadores e ministros, não compareciam aos meetings. Havia exceções, como se verá no terceiro capítulo. O próprio Seabra se orgulhava de ter sido um dos pioneiros do uso de meetings na Bahia, em sua primeira campanha a deputado federal, mas isso foi no início de sua carreira. De maneira geral, o meeting não era o espaço preferencial dos "grandes homens". Eles apareciam com maior frequência em outros rituais públicos, como as cerimônias de embarque e desembarque, muito comuns em cidades litorâneas, como Salvador.

As cerimônias de embarque/desembarque eram frequentes, pois os políticos de atuação nacional viviam em constantes viagens, principalmente para o Rio de Janeiro, capital federal, e para a Europa, onde passavam temporadas respirando os ares "civilizados" (e já poluídos) de Paris ou Londres. Suas chegadas e partidas eram motivo de mobilização dos aliados baianos, que aproveitavam para demonstrar publicamente sua lealdade. A programação era extensa e, às vezes, podia começar horas antes da chegada do navio, com a formação de "préstitos" (cortejos) com representantes de "todas as classes", que desfilavam pelas ruas enfeitadas. A "mocidade acadêmica" das três escolas superiores (Medicina, Engenharia e Direito) e da Escola Comercial marcava presença com seus estandartes. Se o político em questão tinha relações com o Centro Operário, a entidade também participava, assinalando o apoio da "classe operária”. Em alguns casos, os conselheiros municipais de Salvador também se juntavam ao cortejo, carregando os símbolos da cidade, o que dava um tom mais solene e oficial ao ritual. 
Os políticos chegavam em grandes navios transatlânticos (paquetes), que não podiam atracar no porto de Salvador por falta de profundidade. Era necessário buscá-los em lanchas, o que dava ensejo a um interessante ritual marítimo. Quando o navio esperado aparecia, o forte de São Marcelo dava sinal e as autoridades, funcionários, bandas de música, comissões de operários, de acadêmicos, entre outros, embarcavam em lanchinhas enfeitadas, que faziam evoluções navais diante do paquete. Logo depois, eles saltavam no navio e começavam as primeiras homenagens, discursos e brindes. $\mathrm{O}$ recém-chegado entrava, então, na lanchinha da autoridade mais graduada (o governador, por exemplo) e, finalmente, descia no porto, também enfeitado, onde ocorriam novos discursos, saudações, música e fogos de artifício. Então, em um carro de tração animal ou automóvel, o homenageado ia para sua casa ou outro alojamento, acompanhado do préstito e das bandas de música, com mais festas e discursos pelo caminho.

É interessante perceber que, apesar de promovidas e dirigidas pelos partidos dominantes, essas cerimônias de embarque/desembarque envolviam grande parte da população de Salvador. Isso ocorria, em primeiro lugar, pela própria disposição da cidade na época, concentrada em torno da baía de Todos os Santos. A partir da Cidade Baixa, e de vários pontos da Cidade Alta, era possível acompanhar a chegada do paquete, o movimento das lanchinhas, a aglomeração no porto, os fogos de artifício. Em segundo lugar, a parte do cortejo era aberta e se prestava a manifestações diversas, a favor ou contra o homenageado. De fato, era muito comum que grupos contrários expressassem seu repúdio ao adversário, acompanhando com "morras" os "vivas" gritados pelos aliados. As agressões verbais podiam, eventualmente, ser acrescidas de hortaliças podres e lixo, como aconteceu no retorno do ex-governador Luís Viana da Europa, em 1900. Como já estava incompatibilizado com o novo governador (Severino Vieira), este foi responsabilizado pela chuva de imundices e vaias que marcou, simbolicamente, o início do ostracismo do antecessor. 
Os rituais de embarque/desembarque tinham, normalmente, duas etapas. Uma delas era pública e aberta, como se viu, mas havia outra parte mais fechada e restrita. Eram os almoços e jantares, banquetes exclusivos e elegantes, dos quais tomavam parte apenas os elementos socialmente privilegiados, capazes de entender cardápios em francês e de manusear taças de cristal, usadas nos brindes com champanhe.

Os banquetes, evidentemente, não eram limitados aos momentos de embarque/desembarque, mas contituíam um ritual específico na dinâmica da Bahia republicana. Eles podiam ocorrer em hotéis, teatros ou residências. Eram eventos restritos aos senhores da política e aos inevitáveis jornalistas, que os narravam nas gazetas do dia seguinte. A posição dos convidados na mesa era significativa, com lugares reservados aos elementos mais importantes. Estar sentado em lugar próximo ao homenageado principal, do político recém-chegado da capital, por exemplo, era uma distinção. $\mathrm{O}$ momento do brinde era o ponto alto do banquete, em que eram proferidos discursos laudatórios. Os jornais registravam os nomes dos convivas e o cardápio completo, com entradas, pratos principais, sobremesas, cafés e licores, para que os não convidados pudessem, ao menos, imaginar e desejar o gosto do poder.

As conferências públicas também eram eventos formais, mas menos exclusivos. Elas podiam estar, ou não, relacionadas a campanhas eleitorais. Ocorriam, geralmente, em teatros, sendo o Politeama Baiano e o Cine-teatro Jandaia os mais recorrentes, já que o Teatro São João, o maior, mais imponente e tradicional da Bahia, estava muito mal conservado. Em geral, as conferências eram abertas ao público, mas seguiam certas normas de hierarquia: as frisas e os camarotes, por exemplo, eram reservados às "excelentíssimas famílias" das classes privilegiadas. Os políticos mais destacados ficavam no palco, ao longo de uma grande mesa, posicionados como atores principais do drama político que se desenrolava. O público comum devia se espalhar nos espaços menos valorizados do teatro, ou ficar do lado de fora, apreciando a chegada dos carros que traziam as mais destacadas autoridades. 
Meetings, cerimônias de embarque/desembarque, banquetes e conferências são apenas alguns rituais políticos da Bahia republicana. Havia outros, como as visitas de autoridades a instituições (Associação Comercial e Centro Operário, por exemplo), inaugurações de obras públicas, bailes oficiais, aniversários de governo, entre outros.

Sem aprofundar o estudo desses rituais, eles trazem à tona aspectos interessantes que precisam ser apontados. Chama a atenção, em primeiro lugar, a expressiva presença popular em alguns deles. As fotos da multidão nas ruas em 1912, para recepcionar Seabra, e em 1919, para aplaudir Rui em sua campanha presidencial, são evidências disso. Mas, a participação da população se dava de uma forma que não contestava, antes legitimava a configuração de poder excludente que vigorava. Pode-se dizer que, além de diferenciar quem estava dentro e quem estava fora dos grupos e partidos, os rituais em foco promoviam uma ordenação entre os que estavam em cima e os que estavam embaixo. Eles reforçavam a visão da política como algo que deveria ser conduzido pelos chefes ou "próceres" - esse último termo, muito usado na época, tem como origem etimológica a ideia de "ponta", simbolizando alguém que se destaca dos outros, que está acima dos demais. Era, no fundo, a permanência de um liberalismo profundamente senhorial e excludente, apesar da inclusão da multidão como elemento no jogo político.

Mas, o que pensava essa multidão que enchia as ruas de Salvador, que aplaudia, que jogava tomates estragados e confetes nesses "próceres” tão celebrados? Sem conhecer estudos específicos sobre o tema, pode-se arriscar algumas hipóteses. Parte dos participantes nos rituais políticos devia estar ali por curiosidade, atraídos pela música, pelos fogos, pelo movimento de gente. Outros seriam ligados, de alguma forma, a um dos grupos em confronto, e participavam para afirmar publicamente sua solidariedade, o que poderia se reverter em ganhos variados: um emprego, um cargo público, uma promoção, uma ajuda financeira para minorar as dificuldades da vida cotidiana. Algumas pessoas participavam para evitar retaliações, como funcionários públicos e 
empregados de companhias ligadas aos grupos políticos em disputa. $\mathrm{Ou}-$ tros, eram arregimentados por meios diversos.

A retórica e os rituais eram armas importantes na face pública, no proscênio do drama político que se desenrolava na República. Mas, esses embates não ocorriam sem que se processassem ações na complexa dimensão oculta dos "bastidores" políticos. Será preciso, portanto, entrar agora no reverso dessa iluminada ribalta, isto é, em um território obscuro e pouco estudado, no qual eram tecidas negociações diversas, de grande ou pequena monta, mas sempre de relevância para a compreensão da dinâmica do lado de dentro do poder.

\section{Pequena política, grandes corporações}

Em 1907, como se verá no capítulo seguinte, o senador Rui Barbosa e o ex-ministro J. J. Seabra se enfrentaram em um duelo verbal. Inicialmente, era quase um monólogo de Seabra, que procurava se vingar do conterrâneo, a quem atribuía a "degola" da sua eleição pelo estado de Alagoas. Sem mandato, jogado ao ostracismo, Seabra publicou uma série de oito artigos no Jornal do Comércio (RJ), com denúncias contra Rui. (CASTRO, 1990) O senador não se dignou a responder à maioria. Mas, quando Seabra aludiu a uma suposta intriga de Rui contra o barão do Rio Branco, prestigiado ministro do Exterior, viu-se obrigado a responder. O resultado é que o discurso de Rui em sua despedida do Senado, antes de embarcar para a conferência de Haia, é quase todo dedicado a seu desafeto baiano. (BARBOSA, 1907, v. 34, t. 1, p. 27-74)

Segundo a denúncia de Seabra, Rui o havia procurado no Ministério da Justiça, em 1902, dizendo que os militares não aceitariam o Tratado de Petrópolis, que estava sendo acertado pelo barão como solução da chamada "questão do Acre". Rui teria dito a Seabra para falar com o presidente Rodrigues Alves, sugerindo a exoneração do barão do Ministério 
das Relações Exteriores, para evitar uma ação militar contra o governo. Segundo Seabra, isso não passava de uma intriga para derrubar o barão, cotado como candidato na eleição presidencial seguinte. Rui teria inventado a história para eliminar um virtual competidor ao cargo.

Sem discutir a veracidade ou não da denúncia, interessa ver como Rui respondeu às acusações. Ele não apenas negou as palavras de Seabra, mas fez também um histórico de suas relações com ele, apontando a posição subordinada que o adversário ocupava e os favores que lhe devia. Rui afirmou textualmente que Seabra fôra seu "cliente" nos primeiros anos da República. Ao criticar o comportamento do antigo aliado, teceu as seguintes considerações:

A amizade pode extinguir-se, pode sofrer abalos profundos, romper-se totalmente, não deixar senão recordações dolorosas, mas o homem de bem a respeitará sempre, ainda depois de extinta, nos fatos íntimos que ela cobriu e que se passaram no seu seio.

Foram estas as leis, foram estas as tradições, foram esses os deveres que se romperam para a perpetração desse atentado em que a vítima fui eu, diretamente.

Mas abriu-se uma escola, uma escola funesta, criou-se um precedente fatal para a vida política, para a educação dos homens públicos, levando-nos ao espírito a desconfiança, tornando impossíveis as solidariedades de honra, sem as quais, na vida pública, as grandes campanhas são impossíveis [...]. Se não confiarmos nos outros, se não pudermos ter a certeza de que os fatos passados no íntimo das relações da amizade política estarão vedados para sempre à publicidade indiferente e curiosa, a que ficam reduzidas, entre nós, essas relações?

Quem poderá mais depositar nos seus companheiros, nos seus aliados, nos seus correligionários, a fé de que depende o bom êxito de todas as campanhas morais? (BARBOSA, 1907, v. 34, t. 1, p. 35-36)

Nota-se, claramente, nesse discurso de Rui, a distinção de duas dimensões. Uma, a dimensão pública, dos debates nos jornais e na tribuna. Outra, a dimensão privada da "amizade", das "solidariedades de

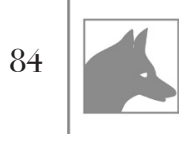


honra", dos bastidores. Havia um entendimento tácito dos "próceres" de que certas relações e ações deveriam se processar nessa face oculta, longe dos olhos ignorantes do público. Seabra havia infringido essa norma de conduta ao trazer para a cena pública fatos ocorridos no domínio reservado dos bastidores.

A importância da "pequena política", especialmente em sua faceta "clientelista" tem sido foco de debates na historiografia brasileira, mas as discussões têm se voltado principalmente para o Império. Na República, há poucos estudos específicos sobre esse aspecto das relações políticas, até por certa confusão com o problema do coronelismo, com o qual ele certamente se relaciona, mas não se confunde. Clientelismo e coronelismo são fenômenos imbricados, muitas vezes superpostos, porém distintos. (CARVALHO, 2000)

Como eram as relações pessoais entre Rui e Seabra? Já se registrou anteriormente a diferença de poder político entre eles no início da República. Rui afirmou que Seabra era seu "cliente". Essa situação assimétrica pode ser ilustrada por uma carta que o pai de Seabra endereçou a Rui em 1892. Além de agradecer pelo que considerou uma "desinteressada e monumental defesa" que Rui fez de seu filho, desterrado por Floriano Peixoto, ele também se declarava grato pela promoção que Rui arranjou, atendendo à solicitação de Seabra ("a pedido de meu filho doutor”), para outro filho seu, na Alfândega da Bahia. Concluiu declarando que "só um brasileiro ingrato" negaria a Rui um voto "para ocupar os primeiros lugares do país e poder, assim, dotá-lo do engrandecimento de que tanto precisa”. (FCRB/ARB/CRUPF 1332.3/2 20/05/1892)

Em janeiro de 1893, o próprio Seabra dirigiu-se ao senador Rui Barbosa, em carta reservada. Depois de louvar os "inexcedíveis méritos intelectuais, morais e patrióticos" do conterrâneo, Seabra pediu que não se esquecesse dele, quando fosse tratar com os políticos da Bahia sobre a futura chapa eleitoral. Solicitou que seu nome fosse colocado em um distrito “onde sejam impotentes as imposições do governo [federal]”. 
O pedido tinha cabimento, pois Seabra ainda era visto como feroz adversário pelo governo. Disse que não gostaria de fazer parte de uma chapa com a presença de militares, mas que se resignava ao que Rui decidisse, pois o considerava "chefe das hostes em que milito". Aproveitou, ainda, para dizer que continuava na campanha em favor de Rui para a presidência da República, e que acreditava em sua vitória. (FCRB/ARB/CRUPF 1332.1/1 25/01/1893)

Ora, mesmo com todas as finuras de retórica, que preconizavam a modéstia e a reverência aos amigos políticos, é evidente a posição inferior de Seabra nos anos iniciais da República. Outras cartas indicam que ele serviu como mensageiro e mediador em negociações de Rui com chefes da política baiana. (FCRB/ARB/CRUPF 1332.1/1 30/09/1896)

Essa situação desprestigiada se alterou significativamente, a partir de 1902, com a ascensão de Seabra ao ministério de Rodrigues Alves. Apesar de ainda chamar Rui de "mestre", o tom de suas cartas passou a ser menos formal e menos humilde. Já não era a correspondência entre chefe e discípulo, mas entre um ministro e um senador - entre dois "próceres”. Em dezembro de 1902, por exemplo, o ministro Seabra pediu a Rui que fosse à comissão de Finanças do Senado falar com o senador Segismundo Gonçalves sobre certas emendas ao orçamento do seu ministério. "Ele disse encontrar alguma dificuldade oposta por três membros”, explicou Seabra, "oposição que desaparecerá com a sua presença. Como verá, as emendas são justíssimas e têm como objetivo atender a serviços inadiáveis". Seabra usava, em seu benefício, o imenso prestígio de Rui, e colocava o "eminente mestre" para trabalhar em seu favor no Senado. Em 1903, ele já se julgava à altura de se dirigir, em carta, ao "excelentíssimo amigo e colega sr. conselheiro Rui Barbosa”. (FCRB/ARB/ CRUPF 1332.1/1 09/12/1902; 1\%/03/1903, grifo nosso)

A relação tornou-se, então, mais de igual para igual, embora Seabra não perdesse oportunidade de reverenciar e de agradar Rui. Provavelmente, contava com o apoio do seu prestígio e da sua influência para suas 
pretensões na Bahia. Como ministro, não só se esforçava para atender aos pedidos de Rui, como deixava claro que ele gozava de deferência especial. Alguns exemplos dessa postura, extraídos de cartas de Seabra a Rui, entre 1903 e 1905:

Sabe que suas ordens só não serão religiosamente cumpridas quando for absolutamente impossível fazê-lo. (FCRB/ARB/CRUPF 1332.1/1 07/07/1903)

O que for possível fazer, farei, com a simpatia que agradavelmente impõe sua recomendação. Mande-me suas ordens. (FCRB/ARB/CRUPF 1332.1/1 31/07/1903)

Recebi sua ordem referente ao Dr. Paes de Figueiredo. Não preciso dizer como as cumpri, quanto ao acolhimento benévolo. Tenho agora todo interesse em colocá-lo e oportunamente não me esquecerei de que ele é recomendado pelo meu ilustre mestre. (FCRB/ARB/CRUPF 1332.1/1 11/08/1903)

Os seus pedidos nunca parecerão impertinentes a mim, que tenho prazer em recebê-los [...] Não tenha, pois, cerimônia em mandá-los, que o acolhimento será sempre de simpatia. (FCRB/ARB/CRUPF 1332.1/1 29/12/1903)

Sabe que eu não lhe nego, nem posso negar coisa alguma a uma simples ordem sua, menos ainda quando se dá em termos como os desta carta, a que não resistiria a mais rebelde vontade. (FCRB/ARB/ CRUPF 1332.1/1 03/01/1905)

Os trechos citados também deixam claro que Rui recorreu a Seabra diversas vezes, com pedidos de seus protegidos. Até a esposa de Rui, Maria Augusta, mandou solicitação ao ministro para que um menino fosse admitido no Ginásio Pan-Americano como aluno gratuito, e foi atendida. (FCRB/ARB/CRUPF 1332.1/1 18/03/1903) Do exposto, já se vê que Rui e Seabra já não mantinham a mesma relação do início da República. Era, agora, uma relação de mão dupla, embora cada um tivesse suas características mais destacadas: em Rui, o lado intelectual pesava mais, enquanto Seabra, naquelas circunstâncias, tinha mais peso político. 
As relações de clientelismo e favorecimento recíproco faziam parte do cotidiano dos políticos da Primeira República. Todos precisavam lidar com isso, inclusive Rui e Seabra. Os dados disponíveis sugerem que Seabra tinha muito mais facilidade e desembaraço em lidar com essas questóes do que Rui. Colocado em um patamar tão elevado de erudição e solenidade, tão acima dos homens comuns, o ilustrado senador parecia um tanto inacessível às demandas da política dos pedidos, contra a qual costumava protestar em discursos inflamados. (CARVALHO, 2000) Diante disso, muita gente preferia pedir os favores através de intermediários, como o filho Alfredo Rui e o cunhado Carlos Viana Bandeira (o Carlito), do que aborrecer a Águia de Haia com questões rasteiras, que certamente seriam consideradas por ele pouco nobres.

Não eram todos que tinham esses pudores, é claro. Dentre as muitas cartas de pedido guardadas no acervo de Rui, há várias de políticos baianos, algumas muito interessantes pela arte com que os missivistas enfeitavam suas solicitações. $\mathrm{O}$ advogado e político José Gabriel de Lemos Brito, por exemplo, escreveu a Rui dizendo que, impulsionado pela "quase idolatria" que lhe dedicava, acalentava o projeto de escrever uma biografia sua, intitulada Rui Barbosa: sua vida e sua obra. Chegou a detalhar o futuro livro, com o conteúdo previsto para cada um dos quatro volumes. Arrematou com o pedido: "se o grande baiano entender ser tarefa para minhas forças, irei meter ombros no estudo preliminar desses trabalhos. Para isso, bastar-me-á que Rui Barbosa entenda conseguir uma posição federal que me dê a calma e o tempo necessário para a vasta obra. Bastará um gesto do meu grande amigo junto ao Miguel Calmon para que esse ilustre ministro consiga para mim o lugar desejado". (FCRB/ ARB/CRUPF 244 22/10/1908)

Amigos próximos de Rui, como o médico baiano Artur Imbassaí, tinham liberdade de pedir o que quisessem. Imbassaí era tão íntimo que suas cartas dispensavam as formalidades de estilo e eram encabeçadas simplesmente por "Meu caro Rui" ou "Meu Rui” (uma intimidade que 
Seabra, por exemplo, nunca teve). Em 1903, esse amigo pediu a Rui que lhe arranjasse um emprego no ministério de Seabra. Mas, Imbassaí teve a má sorte de solicitar uma nomeação no setor de saúde, dirigido por Osvaldo Cruz. Apesar de ainda ser quase desconhecido, Osvaldo Cruz havia imposto uma condição para aceitar o cargo: o total controle sobre seu departamento, inclusive sobre as nomeações e demissões. Com espanto, Imbassaí contou a Rui que o diretor da Saúde Pública tinha autonomia até de demitir quem lhe conviesse, se o trabalho não fosse satisfatório. Vendo que Seabra estava tendo dificuldades em nomeá-lo por causa da teimosia do seu subordinado, o amigo de Rui ainda comentou: "Só um ministro muito desgraçado não seria capaz de garantir um candidato seu". (FCRB/ARB/CRUPF 727/1 12/03/1903, 02/04/1903)

$\mathrm{O}$ caso é interessante porque ilustra que a cultura da indicação era a norma, não a exceção. O procedimento de Osvaldo Cruz é que era incomum. Esperava-se que o ministro pudesse nomear quem bem entendesse para o ministério e, se ele não conseguia fazer isso, era sinal de fraqueza. Imbassaí fez a ressalva, no entanto, que Seabra vinha se esforçando para superar as dificuldades. Ele relatou que o ministro, com seu jeito peculiar de falar, o havia repreendido por aborrecer Rui com assunto tão corriqueiro. As palavras de Seabra, segundo ele: “Agora sim, seu Artur, é que V. está merecendo uma demissão, por ter ido perturbar a paz do meu amigo Rui... Isso não se faz". A partícula "seu" foi grifada no original, como a destacar o tom informal da fala de Seabra. Em um registro formal, era esperado que ele chamasse o médico Imbassaí de "doutor".

Seabra lidava naturalmente com a complexa dinâmica dos favores, conforme o comportamento vigente. Não tinha vergonha de pedir e se esforçava para atender. Em 1896, ao recomendar a Rui um protegido seu, explicou que o rapaz era "muito acanhado" e que, talvez por isso, não havia seguido sua recomendação de "lembrar-lhe sempre o pedido", por achar que se tornava importuno. (FCRB/ARB/CRUPF 1332.1/1 26/10/1896) Seabra não sofria dessas inibições. Da mesma forma, facilitava o acesso aos seus 
próprios “clientes”. Quando ministro, instituiu um evento semanal nas noites de quinta-feira, oportunidade para estabelecer contatos em um ambiente agradável, ao som de música. Em biografia escrita quando ele estava no ministério, com o propósito de enaltecê-lo, Melo Moraes Filho descreveu a atitude de Seabra nessas recepções:

De uma urbanidade insinuante e majestosa, inteligência clara, justa, precisa, nada tendo de burocrático, de protocolar, o ministro do Interior acolhe entre os braços os convivas da noite, liberalizando maneiras cortesãs, distinções espontâneas. (MORAES FILHO, 1905, p. 101)

Nessas recepções do ministério, a frequência era, provavelmente, de pessoas das classes mais privilegiadas, como o próprio Rui, que recebeu um convite, hoje guardado em seu acervo. Era um desses rituais políticos mais restritos, já mencionados. Mas, a habilidade de Seabra em fazer e receber pedidos, sua naturalidade em lidar com a "pequena política", pode ser compreendida como uma característica marcante, em sua trajetória política, também na relação com pessoas de outras classes sociais. Essa é, a nosso ver, uma chave importante para a compreensão de sua ligação duradoura com o major Cosme de Farias, já mencionado, elemento fundamental na articulação do apoio dos setores populares de Salvador ao seabrismo.

Cosme de Farias era uma figura peculiar no horizonte político da Bahia republicana. Nascido em família de parcos recursos, não teve acesso à educação superior e aprendeu os ofícios de rábula e repórter na prática. Frequentava diversos sindicatos e associações, inclusive o Centro Operário da Bahia. Como rábula, advogava a favor de trabalhadores em greve, servindo de intermediário junto aos patrões. Promovia meetings contra a "carestia da vida", pedindo providências das autoridades para reduzir o preço dos alimentos. Mais tarde, o combate ao analfabetismo seria sua principal bandeira. Em sua longa trajetória como político, líder popular, representante de trabalhadores, Cosme se mostrava guiado por um ideal de assistência e caridade que o levava

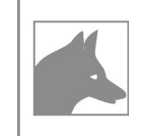


a tentar minorar as dificuldades do próximo. Não pedia nada para si, o que pode ser comprovado pela extrema pobreza em que viveu e morreu. A abnegação pessoal reforçava sua imensa popularidade entre os pobres de Salvador. (SANTos, Mônica, 2005)

Como Seabra, Cosme de Farias não tinha inibição de pedir. Ele batia em todas as portas, em favor dos mais pobres e necessitados. Ao encontrar a porta de Seabra aberta, ficou encantado. Ali estava um político poderoso, um "prócer" da República, mas carismático, acessível, eficiente na intermediação de empregos, doações e benefícios. Firmou-se, então, uma relação vantajosa para ambos. Sem bases na política baiana tradicional, dos chefes do interior, Seabra conquistou um extraordinário promotor de seu grupo junto ao povo de Salvador, como já se registrou. Em troca, Cosme tinha acesso a um político que, além de se esforçar em atender pedidos, era capaz de se comunicar bem com a população menos escolarizada. A adesão de Cosme durou para sempre. Até morrer, em 1972, ele ainda se declarava seabrista.

Registre-se, ainda, que Seabra elegeu Cosme de Farias deputado estadual em 1915, 1917, 1919 e 1921 (SANTOS, Mônica, 2005, p. 89-94), algo absolutamente incomum na Bahia da Primeira República, em se tratando de uma pessoa de origem verdadeiramente popular, sem dinheiro e sem anel de bacharel. Até então, os líderes operários mais destacados e articulados ao poder vigente, como Prediliano Pita e Ismael Ribeiro dos Santos, haviam chegado apenas ao Conselho Municipal. A eleição de Cosme para a Câmara Estadual era excepcional. Além de dimensionar sua importância para a política seabrista, essa distinção também pode ajudar a explicar o vínculo de gratidão e afeição que se firmou entre Cosme e seu "chefe" político.

Os favores pessoais, empregos e promoções não eram os únicos elementos em jogo nessa face reservada da política brasileira. Seabra, Rui e seus contemporâneos também precisavam lidar com as relações que se estabeleciam com empresas privadas que tinham interesse em angariar o apoio dos políticos mais poderosos do país. 
O tema das relações dos homens públicos com interesses privados é sempre muito complexo. A legislação republicana proibia a eleição para o Congresso Nacional de diretores ou presidentes de empresas que gozassem de determinados favores do Governo Federal (isenção de impostos, privilégios de juros, concessão de terras, entre outros). Havia, além disso, geral condenação dos desvios e manobras da "advocacia administrativa", definida como o uso das prerrogativas de funcionário público para patrocinar interesses privados. Atualmente, isso se configura como crime previsto no Código Penal brasileiro. Mas, ainda hoje, é difícil definir limites claros entre a "advocacia administrativa", o "lobby", o tráfico de interesses, e a defesa legítima de interesses junto aos órgãos públicos. Na Primeira República, não era diferente.

A atividade parlamentar ocorria em apenas quatro meses do ano. Os homens que se dedicavam a ela não abandonavam suas atividades profissionais. A questão é que muitas dessas atividades tinham uma interface com o Estado. Os limites entre o que era considerado aceitável nessas relações eram, então, fluidos e controversos.

Não se pretende aqui fazer um mapeamento de todas as empresas que se relacionaram com Rui Barbosa e Seabra ao longo de suas trajetórias políticas, nem analisar quais dessas ligações eram consideradas aceitáveis, dentro dos parâmetros da época. Em geral, o material pesquisado indica que tanto Rui como Seabra eram considerados homens honestos pelos contemporâneos, embora eles tenham trocado sérias acusações em seus momentos de maior confronto, como se verá no terceiro capítulo.

Um exemplo de como eram complexas essas ligações, e das interferências desses negócios na política baiana, pode ser encontrado na correspondência de Rui com o amigo e parente João de Assis Lopes Martins. Em 1910, ele pediu ao senador que escrevesse uma carta ao governador da Bahia, Araújo Pinho, para que seu grupo conseguisse a preferência sobre um trecho da Viação Baiana, na parte que se ligava a Minas Gerais. Não ficou claro, na documentação consultada, que tipo de serviço deve- 
ria ser desenvolvido na ferrovia, mas Martins disse que era um "negócio grande, que pode nos dar a independência financeira". Martins e Batista Pereira (genro de Rui) faziam parte da sociedade, mas somente um terceiro sócio (Gabriel Penteado) deveria aparecer publicamente. Apesar dessas precauções, Martins assegurava que não havia nada de errado com a pretensão. "Isto é um serviço que deve ser feito por este ou aquele, cumpre-nos aproveitar todos os nossos elementos para obtermos a preferência. Só isto ambicionamos. Não se trata propriamente de um favor. Os mandatários terão toda a vantagem de empreiteiros que mantenham boas relações com o governador". (FCRB/ARB/CRUPF 896/3 25/12/1910)

Já se vê que a indicação, em si, não era tratada exatamente como infração ao bom andamento dos negócios públicos, embora se soubesse que isso não seria bem visto, caso aparecesse nos jornais. Daí a preocupação em ocultar a participação dos parentes de Rui no negócio. Aconteceu, porém, que Seabra havia acabado de ser empossado ministro da Viação, e prometeu rever todos os contratos firmados pelo seu antecessor, alegando que continham irregularidades. $\mathrm{O}$ mesmo Martins, em nova carta, aprovou os atos do ministro recém-empossado, mesmo sabendo que seus negócios poderiam ser prejudicados com as medidas:

O Seabra está convencido de que houve grande comedeira na Viação Baiana e procura meios de anular o contrato, do qual depende o nosso trecho. Não quero analisar os fundamentos da suspeita do Ministro [...] Apesar de não nos atingir a roubalheira, estamos pagando pelo que não fizemos. O nosso contrato é com a Caisse [banco francês que emprestou dinheiro para ferrovias na Bahia], e sobre ela iremos caso o Seabra realize seus intentos, aliás plenamente justificados, a dar crédito ao que se diz. (FCRB/ARB/ CRUPF 896/3 07/01/1911, grifo no original)

Mais tarde, Rui criticaria publicamente essa revisão dos contratos da Viação, argumentando que Seabra beneficiou determinadas empresas, e que sua ação moralizadora era apenas de fachada. Mas, pelo menos de acordo com as cartas de Martins desse período, o grupo ligado a Rui não 
foi prejudicado com a medida. Com sua proverbial habilidade, Seabra conseguiu remanejar as coisas de modo que, ao fim das contas, a Caisse ampliasse a quilometragem de suas ferrovias na Bahia. Aparentemente, o ministro prometeu a Martins e Batista Pereira um trecho equivalente ao inicialmente previsto. Não temos informações se isso foi cumprido, mas, em fins de janeiro de 1911, Martins escreveu uma carta otimista a Rui, dizendo que a Bahia iria ficar "muito bem servida de estradas de ferro" com a reforma de Seabra. (FCRB/ARB/CRUPF 896/3 29/01/1911)

O grupo seabrista também tinha ligações próximas, até de parentesco, com pessoas interessadas nas estradas de ferro da Bahia. O engenheiro Miguel de Teive e Argolo, concessionário de várias ferrovias desde o Império, era sogro de Muniz Sodré (deputado e senador federal pelo grupo de Seabra e primo do futuro governador seabrista Antônio Muniz).

As ferrovias eram alvo de intensa disputa, não só pelo seu valor econômico, como também pelo poder político de facilitar os transportes para esta ou aquela região. Era uma das áreas principais de interesse do capital estrangeiro que, desde o século XIX, vinha se expandindo para países periféricos como o Brasil. Até a década de 1890, essa expansão se deu preferencialmente em forma neocolonialista, na África e a Ásia. Na virada do século $\mathrm{XX}$, porém, a disputa imperialista passou a priorizar "privilégios e monopólios para exploração dos recursos naturais ou dos mercados consumidores dos países periféricos, entre os quais os latino-americanos". (LAMARÃO, 2002, p. 76) A grande abundância de capitais nos países centrais viabilizava os investimentos na modernização da estrutura de transportes e serviços nos países periféricos, com altos lucros para os investidores.

Além das ferrovias, outra área prioritária para o investimento desses capitais era a geração e distribuição de eletricidade e os modernos transportes e serviços urbanos. Duas das companhias mais poderosas desse setor mantiveram ligações duradouras com Rui e Seabra.

Desde 1905, Rui era consultor jurídico da Rio de Janeiro Tramway, Light and Power Company, mais tarde incorporada à Brazilian Traction,

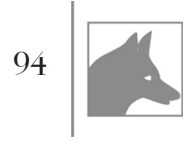


Light and Power, conhecida simplesmente como a Light. O cargo foi obtido através de solicitação que seu cunhado Carlos Viana Bandeira fez ao senador Pinheiro Machado, que, por sua vez, acionou Nilo Peçanha, então governador do Rio de Janeiro. (VIANA FILHo, 2008) A atuação como advogado da Light, em si, não tinha implicações políticas diretas, mas, se o poder do verbo de Rui tinha enorme influência no país, nos jornais, no Parlamento, nos tribunais, como já se apontou aqui diversas vezes, é fácil entender o interesse da companhia em contratá-lo. Como consultor da empresa, Rui emprestava a credibilidade de sua imagem pública para os negócios da Light.

A Light era uma empresa verdadeiramente multinacional. Foi fundada no Canadá, mas alguns de seus donos eram oriundos dos Estados Unidos, de onde vinham seus métodos de gestão. Parte dos capitais provinha da Inglaterra. O grupo também atuava em outros países periféricos, como Cuba, Argentina e México. No Brasil, a Light iniciou seus negócios em São Paulo, passando depois a disputar o concorrido mercado de iluminação, transportes e energia elétrica do Rio de Janeiro. Não demorou para que Salvador, terceira maior cidade brasileira, viesse a despertar o interesse da companhia. (LAMARÃo, 2002; MCDOWALL, 2008)

$\mathrm{Na}$ capital da Bahia, a atuação da Light se deu em sociedade com o magnata norte-americano Percival Farquhar, figura emblemática do capitalismo internacional da época. Em 1905, Farquhar fundou a Babia, Tramway Light and Power Co., com sede na cidade de Portland, nos Estados Unidos, tendo como sócios Frederick Pearson e Alexandre Mackenzie, que também integravam as empresas Light do Rio e de São Paulo. A primeira investida da Babia Light foi a compra da linha de bondes que rodava na Cidade Baixa, então sob controle da alemã Siemens e Halske. Pouco depois, Farquhar adquiriu a inglesa Babia Gas Company e a belga Compagnie de Eclairage de Babia, assegurando presença, respectivamente, nos mercados de iluminação a gás e energia elétrica. (SAMPAIO, 2005; GAULD, 2006, p. 125-131) 
Apesar do início promissor, os negócios da Light na Bahia não foram tão bem sucedidos como no Rio e em São Paulo. Nessas duas cidades, a companhia aumentou progressivamente sua atuação e acabou estabelecendo um virtual monopólio dos transportes, energia e serviços. Era o "polvo canadense" que tudo abarcava com seus tentáculos, no dizer da população. $\mathrm{O}$ monopólio não foi obtido, porém, sem intensa disputa prévia. No Rio de Janeiro, que era o mercado mais atraente do país, a Light entabulou uma luta prolongada contra o grupo Guinle, de capital originalmente nacional, mas articulado a grandes empresas internacionais como a General Eletric, de que eram representantes no Brasil.

A disputa entre os dois poderosos grupos não envolvia apenas a compra de empresas de menor porte, pioneiras nos serviços urbanos brasileiros nas últimas décadas do século XIX, mas também uma definição sobre $\mathrm{o}$ alcance e a validade dos privilégios e concessões públicas que haviam sido oferecidos para estimular essas primeiras iniciativas. Um exemplo: em 1899, William Reid obteve uma concessão para explorar com exclusividade a geração de energia por fonte hidrelétrica para a capital federal. A chamada "concessão Reid" foi repassada ao grupo Light em 1905, mas os Guinle contestaram o privilégio na Justiça. O problema era complicado, pois envolvia a discussão sobre quem detinha o controle sobre os serviços urbanos da capital federal, se o Conselho Municipal, que havia outorgado a concessão, ou o governo federal, responsável por parte da administração da capital. O governo do estado do Rio também interferia na disputa, assim como as diversas instâncias legislativas e judiciárias envolvidas.

Tanto a Light como os Guinle partiram para angariar apoio entre os políticos de maior influência no país. Já se viu que a Rio Light contratou um advogado de peso, o senador Rui Barbosa, que defendeu o monopólio da companhia nos tribunais e na imprensa. Os concorrentes não ficaram atrás, buscando apoio de homens públicos de destaque em defesa da "livre concorrência", que lhes interessava no momento. Usaram também argumentos nacionalistas contra os estrangeiros. Sérgio Lamarão (2002,

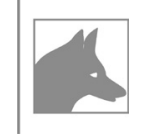


p. 87) observa que os alinhamentos não eram automáticos, mas que era possível detectar elementos vinculados a cada grupo. O barão do Rio Branco, por exemplo, tido como velho amigo de Alexandre Mackenzie, tendia para o lado da Light, enquanto Lauro Müller, ministro da Viação e Obras Públicas, era pró-Guinle. Em geral, a Light vinha conseguindo mais apoio no nível municipal e no governo estadual (Nilo Peçanha), enquanto os Guinle tinham mais força no plano federal (presidência Rodrigues Alves). Ainda assim, após uma prolongada disputa, a Light foi vencedora, assegurando pleno domínio, tanto no Rio quanto em São Paulo.

A derrota nas duas maiores cidades brasileiras reforçou o interesse dos Guinle na terceira maior cidade, Salvador. A capital baiana tornou-se vital para as pretensões do grupo. Não admira, pois, que eles tenham se envolvido de perto com a política e os negócios baianos.

É provável que, desde a atuação no ministério de Rodrigues Alves, Seabra tenha estreitado laços com os Guinle. Em 1911, como se verá, um gerente da empresa (Júlio Brandão) foi escolhido como candidato seabrista à intendência municipal de Salvador. Em troca do apoio prestado, os Guinle tiveram ampla participação nas obras do governo de Seabra, e ainda intermediaram um empréstimo tomado no exterior. Tudo isso será abordado, ainda que brevemente, no último capítulo. Por ora, basta assinalar que os vínculos estabelecidos entre os Guinle e Seabra tiveram efeitos prejudiciais para a Babia Light, especialmente para o poderoso Percival Farquhar, que teve grandes prejuízos. O magnata se arrependeu pelo resto da vida dos empreendimentos em Salvador, que, do alto de sua arrogância civilizatória, considerava a "cidade mais africana e corrupta das Américas”. Segundo Charles A. Gauld (2006, p. 125), mesmo octagenário, Farquhar "não gostava que o lembrassem de suas derrotas nas mãos dos baianos”.

A polarização entre Rui e Seabra na política da Bahia tinha, portanto, mais esse componente: a disputa entre grupos poderosos, com ramificações internacionais, que concorriam pelo mercado de energia, 
transportes e serviços urbanos da Bahia. Apesar de alguns momentos de tensão e mudanças, pois os alinhamentos não eram rígidos e automáticos, pode-se dizer que Rui era ligado à Light, e Seabra, aos Guinle.

Até aqui, foram apontados aspectos da política, sociedade e economia da Bahia republicana, e algumas regras das disputas políticas, tanto em sua face pública, da retórica e dos rituais, como em sua face mais oculta dos favores e intermediações. Esses elementos serão retomados e articulados ao longo do capítulo seguinte, que se concentrará na dinâmica do confronto político entre Rui Barbosa e J. J. Seabra na Bahia da Primeira República. 